\title{
Present and future for technologies to develop patient-specific medical devices: a systematic review approach
}

This article was published in the following Dove Press journal:

Medical Devices: Evidence and Research

\author{
Clara-Isabel López \\ Gualdrón' \\ Edna-Rocío Bravo lbarra ${ }^{2}$ \\ Andrea-Patricia \\ Murillo Bohórquez ${ }^{2}$ \\ Israel Garnica Bohórquez ${ }^{2}$ \\ 'Industrial Design School, Universidad \\ Industrial de Santander, Bucaramanga, \\ Colombia; ${ }^{2}$ Industrial and Business \\ Studies School, Universidad Industrial de \\ Santander, Bucaramanga, Colombia
}

\begin{abstract}
The main purpose of this investigation was to systematically review the literature regarding case studies on patient-specific implants and devices, with the goal of analyzing the process of developing custom-made medical devices. A content analysis was performed to identify design processes and methodologies implemented to develop devices such as implants adapted to bone geometries. Reverse engineering, computer-aided design, simulation of assets, and rapid prototyping technologies were selected according to their interoperability in a process framework for developing new products. Finally, results from the case studies and process stages identified in the consulted research were analyzed. These results showed a relationship between the scope and complexity of the process and the stage of technology integration of the patient-specific device development. The analyzed case studies were characterized by technical, scientific, and multidisciplinary components to achieve research goals. Likewise, integration of technologies using patient-specific technologies is needed for product development that converges into designing devices, such as implants, biomodels, and cutting drilling guides.
\end{abstract}

Keywords: customized implants, virtual planning, integration of CAx technologies, technologies for patient-specific medical devices

\section{Introduction}

Currently, orthopedic research and development studies highlight investigations into the design and manufacturing of patient-specific implants (PSI), also called patient-specific devices (PSD). Such implants or devices provide an effective and precise method for the treatment of a bone fracture or several defects like oncological or congenital malformation. ${ }^{1-4}$ PSDs are designed to be adapted to bone geometry, according to the fracture type to be stabilized. ${ }^{5}$ This concept arose from advances in technology and systems integration, allowing the generation of new design methods. The inclusion of the imaging techniques used in reverse engineering $(\mathrm{RE})$ for the $3 \mathrm{D}$ virtual reconstruction of reference models or biomodels of living tissues has been proposed. ${ }^{6}$ Those tools are sometimes called BIOCAD $^{5}$ or, more traditionally, Computer-Aided Design (CAD). ${ }^{7}$

Results from this technology have been integrated into other software tools used in the design and development of PSDs. ${ }^{8}$ The PSD model is often adapted to $3 \mathrm{D}$ bone geometry. The mechanical behavior of the resulting devices can be evaluated by the finite element method (FEM) using Computer-Aided Engineering (CAE). ${ }^{9}$
Correspondence: Clara-lsabel López Gualdrón

Industrial Design School, Universidad Industrial de Santander, Bucaramanga 680002, Colombia

Tel +57301 3563743

Email clalogu@uis.edu.co 
Some design methods include a visualization phase where a physical model is manufactured by rapid prototyping (RP) for additive manufacturing (AM) or machining by computer numerical control by computer-aided manufacturing (CAM) using subtractive manufacturing (SM). ${ }^{10}$ These tools can be configured in an architecture that supports PSD design and production processes. Specific conditions are needed to design a precise implant in anatomical areas of complex geometry such as the skull, hip, or femur. ${ }^{11-13}$

The current literature does not identify a marker to validate which technologies should be integrated, or which technologies are the most appropriate for the design and development of PSDs to provide optimal treatment for specific patients.

Based on this, it is proposed to define phases of development for technology integration. This work was conducted by consulting research involving successfully implemented PSDs with known software architectures, convergences, and divergences. A systematic review of selected case studies may help identify trends and opportunities to improve the technologies used in developing these devices.

The present article details the materials and methods used in these studies, followed by a content analysis systematic literature review identifying common features related to the design and manufacturing processes, technologies involved in each stage of development, and associated reference practices. Later in the discussion, the results of the literature review are contrasted and analyzed. Finally, the conclusion gives an account of the literature review as support for understanding the integration of technologies in the development of PSDs.

\section{Materials and methods}

In the first stage of the study, an exploratory literature review was carried out on the development of custom medical devices. Different keywords were identified such as BIOCAD, CAD/CAE, RP, CAM, diagnosis, virtual preplanning, implant manufacturing, and PSD design and development. Research questions were defined relating to the process, technological resources, and results in PSD development, as illustrated in Figure 1.

The second stage of this study was to carry out a systematic review of bibliometric to survey relevant technologies. The ISI Web of Science database was searched from 2006-2018, applying the same criteria of quality, inclusion, and exclusion to the selected articles. Although WOS could be set since 2001, according to Meline ${ }^{103}$ a systematic review for contemporary studies could covered prior 10 years. The bibliometric review was run in 2018 . The equation used is shown in Figure 2.

This search identified 394 articles. Duplicate articles were eliminated, as were articles with fewer than 10 citations. Abstracts were then read to identify papers with case studies involving the design of customized implants, highly complex surgical intervention, technologies for patient-specific devices applied to orthopedic surgery,

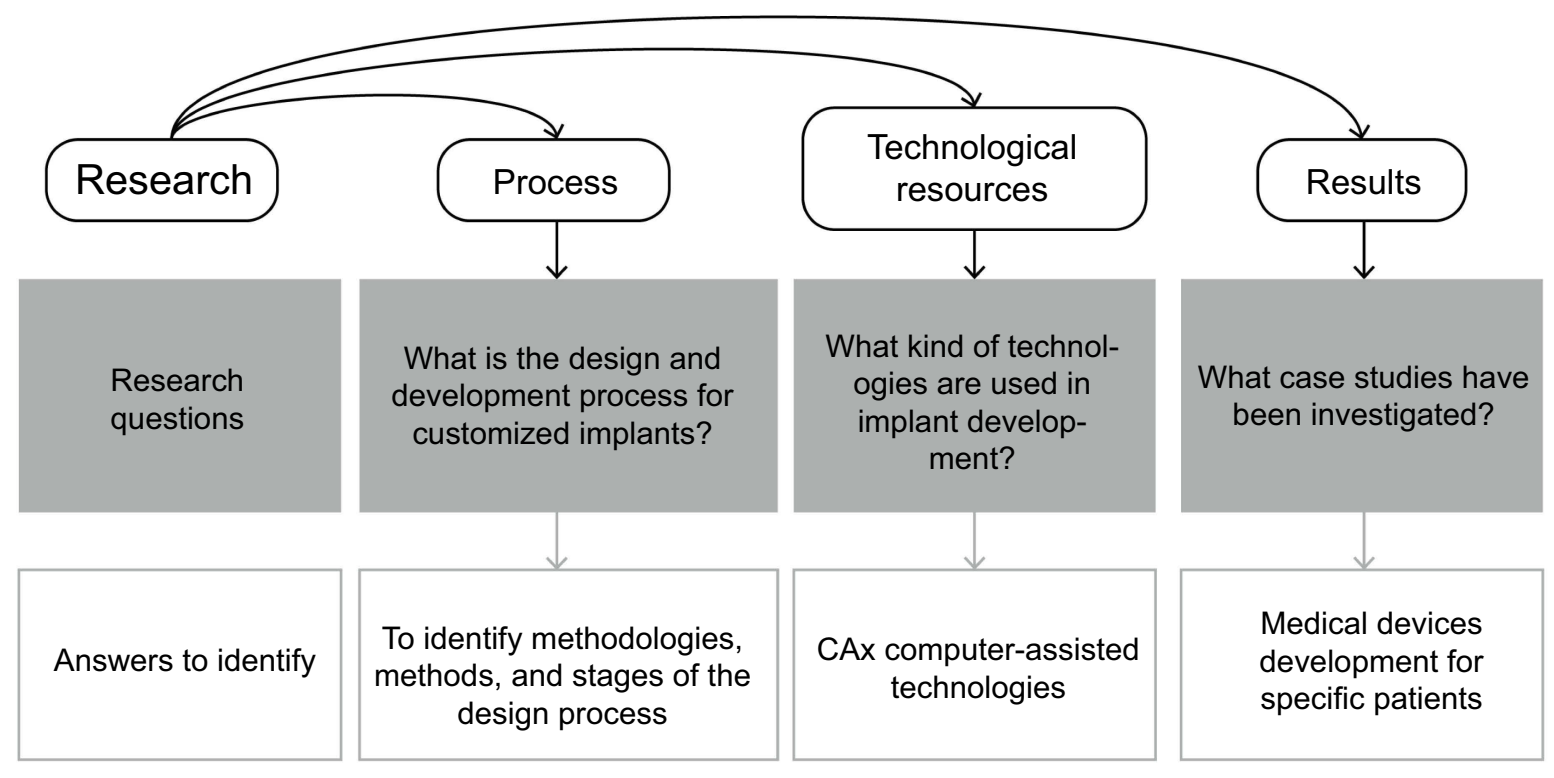

Figure I Research questions for exploratory literature review.

Abbreviation: CAx, Computer-aided Tools. 


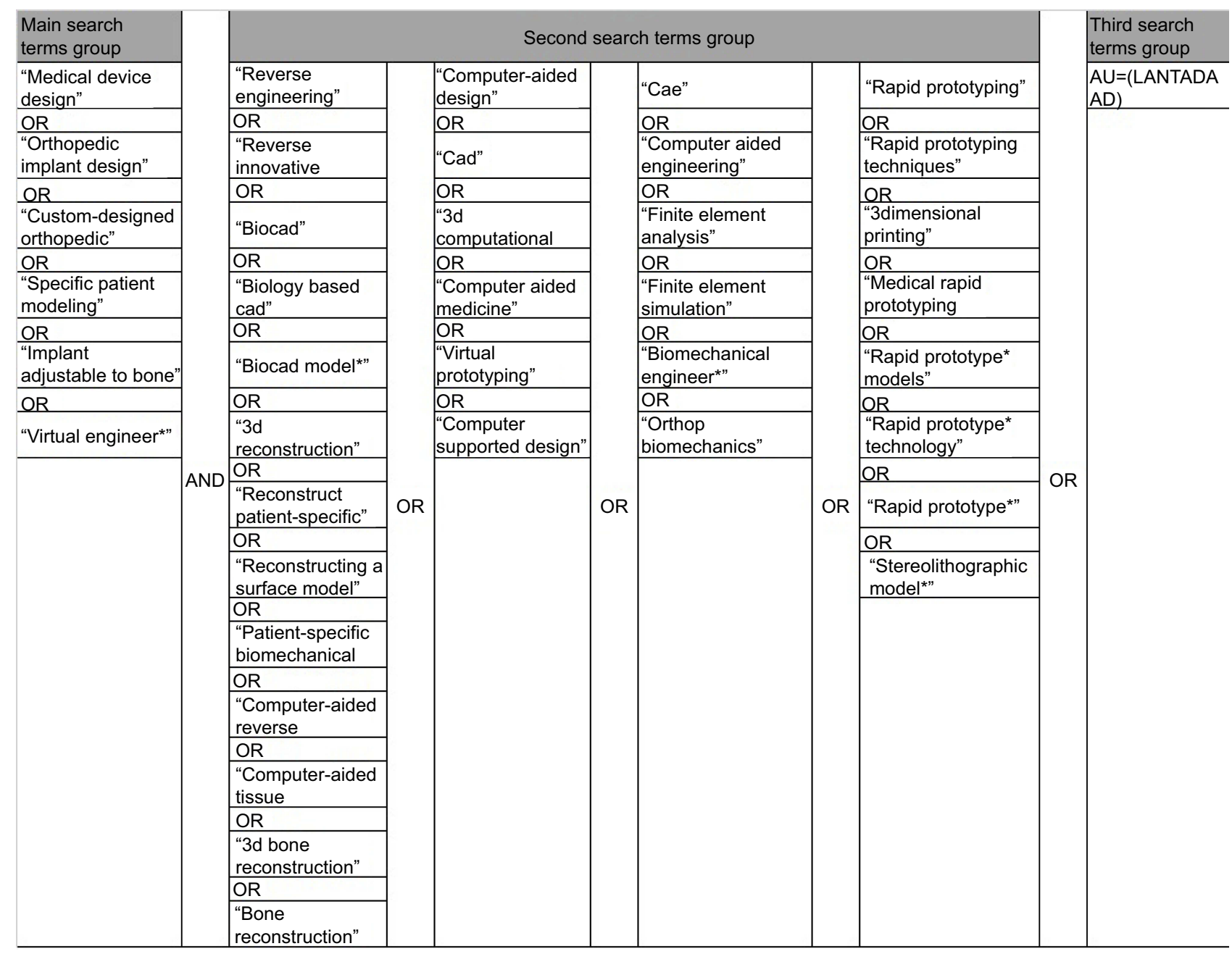

Figure 2 Research equation for literature review.

maxillofacial surgery, orthognathic surgery, and other technologies related to the development of PSDs. From this, 70 articles were selected. Despite time-period selected, seminal papers from 1998-2005 were 10\%, from 2006-2010 were 20\%, from 2011-2015 were 36\%, and from 2016-2018 were 34\%.

In a third stage, a content analysis of the selected scientific articles was carried out to understand the processes used, the tools used, the anatomical regions treated, and the obtained results from the identified case studies of PSDs using computer-aided tools (CAx) technologies. Finally, the bibliometric results were analyzed using the Tree of Science (ToS) web tool to understand trends.

\section{Results}

The selected papers were categorized according to main topics: technology integration models, and trend analysis. The main findings for each topic are given below.

\section{Technology integration models}

The integration of technologies was not explicitly expressed when searching for PSD design case studies. Nonetheless, the 70 documents were analyzed for this content. These studies addressed complex fractures caused by trauma, oncological, or congenital pathologies. The stage in the process of PSD design and manufacture was identified for each study. Also, each stage was associated with the application of a CAx software tool: RE or BIOCAD in virtual reconstruction, CAD in virtual preplanning and modeling, CAE in simulation, and RP in 3D printing, or machining by CAM.

Each technology integration model could also be described by combinations of stages, ie, $\mathrm{RE}+\mathrm{CAD}+\mathrm{CAE}+\mathrm{RP}$ and/or CAM, defining the scope of the technology development of each patient-specific device. ${ }^{14}$ Models with higher numbers of stages involve more technologies, with models possibly having up to 5 
technology types, BIOCAD + CAD + CAE + RP + CAM. In the equation below, it is observed that the combinatorial of these 5 elements "n," without selecting repeated elements and with a restricted order, form groups " $k$ " from a minimum of 2 to a maximum of 5 components, with up to 26 possible combinations.

$$
\Sigma[n ! /((n-k) ! k !)]=26
$$

A total of 8 applied integration models were identified. The model with the highest number of cases was the integration of BIOCAD + CAD + RP with a frequency of $38.6 \%$, followed by the BIOCAD + CAD + CAE + RP model with $21.4 \%$ of cases. The BIOCAD + CAD + RP + CAM model accounted for $14.3 \%$ of cases, and the BIOCAD + CAD + CAE model accounted for $11.4 \%$ of cases.

The BIOCAD + RP model accounted for $7.1 \%$, the $\mathrm{CAD}+\mathrm{CAE}$ and BIOCAD + RP models accounted for $2.9 \%$ each, and the BIOCAD + CAD + CAM model represented only $1.4 \%$ of cases. Figure 3 shows the frequencies observed for each technology integration model.

The type of medical device or process was classified, according to the technology integration model implemented in each study. PSIs were the most explored products obtained by RP and CAM in the case studies, representing $62.9 \%$. The biomodel was the next most studied, representing $41.4 \%$. Surgical drilling or cutting guides were developed in $21.4 \%$ of the studies. The virtual and physical pre-planning carried out in CAD represented $25.7 \%$ and $24.3 \%$ of the studies, respectively. The least explored product was the FEM mechanical simulation associated with CAE, which represented $18.6 \%$ of the cases. These results are shown in Figure 4.
Some implementation patterns were identified. As evident in the matrix of correlations in Table 1, there is a strong incidence between the biomodel and physical simulation, implant, and surgical guide, physical simulation and implant, and virtual preplanning with a surgical guide, among high values of $0.75-0.99$. A moderate correlation was observed for values of $0.40-0.74$, between biomodel and surgical preplanning, physical simulation and FEM analysis, virtual preplanning and implant, FEM analysis and implant, and implant with cutting guide. A low correlation was observed with values close to 0 , , between biomodel and FEM analysis, physical simulation and virtual preplanning, and physical simulation with cutting guide. Negative values have revealed an inverse relationship between virtual pre-planning with FEM analysis, and FEM analysis with the use of cutting guides.

The analysis by anatomical regions studied for the development of custom medical devices yielded 93 case studies reported from the 70 articles analyzed. Of the cases, $57 \%$ were related to reconstructive surgeries of the skull and face, while $43 \%$ were orthopedic surgery cases.

Papers were categorized according to the technology integration models, PSDs, and the anatomical regions studied, as shown in Table S1.

The regions with the highest number of case studies were the maxillofacial area, representing $32.3 \%$ of cases, and the skull vault, representing $17.2 \%$. Pelvic fractures represented $12.9 \%$ and the femur represented $11.8 \%$ of the case studies. Case studies of the hands, feet, knee, and humerus were observed with less frequency. The data detailing the anatomical areas in the case studies are shown in Figure 5.

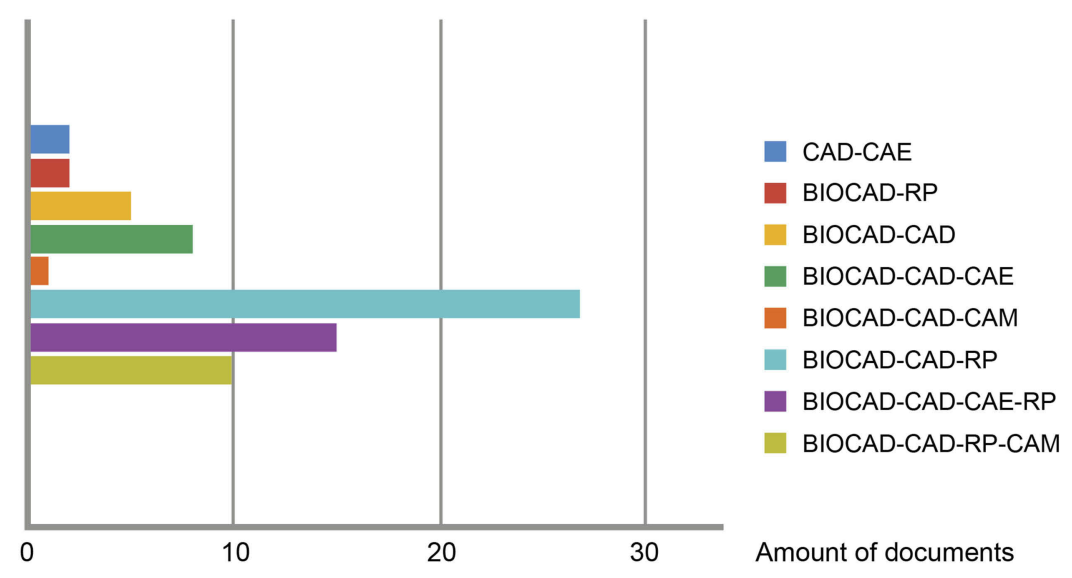

Figure 3 Frequencies of technology integration models observed. Abbreviations: BIOCAD, Biological Computer-aided Design; CAD, Computer-aided Design; CAE, Computer-aided Engineering; CAM, Computer-aided Manufacturing; RP, Rapid Prototyping. 


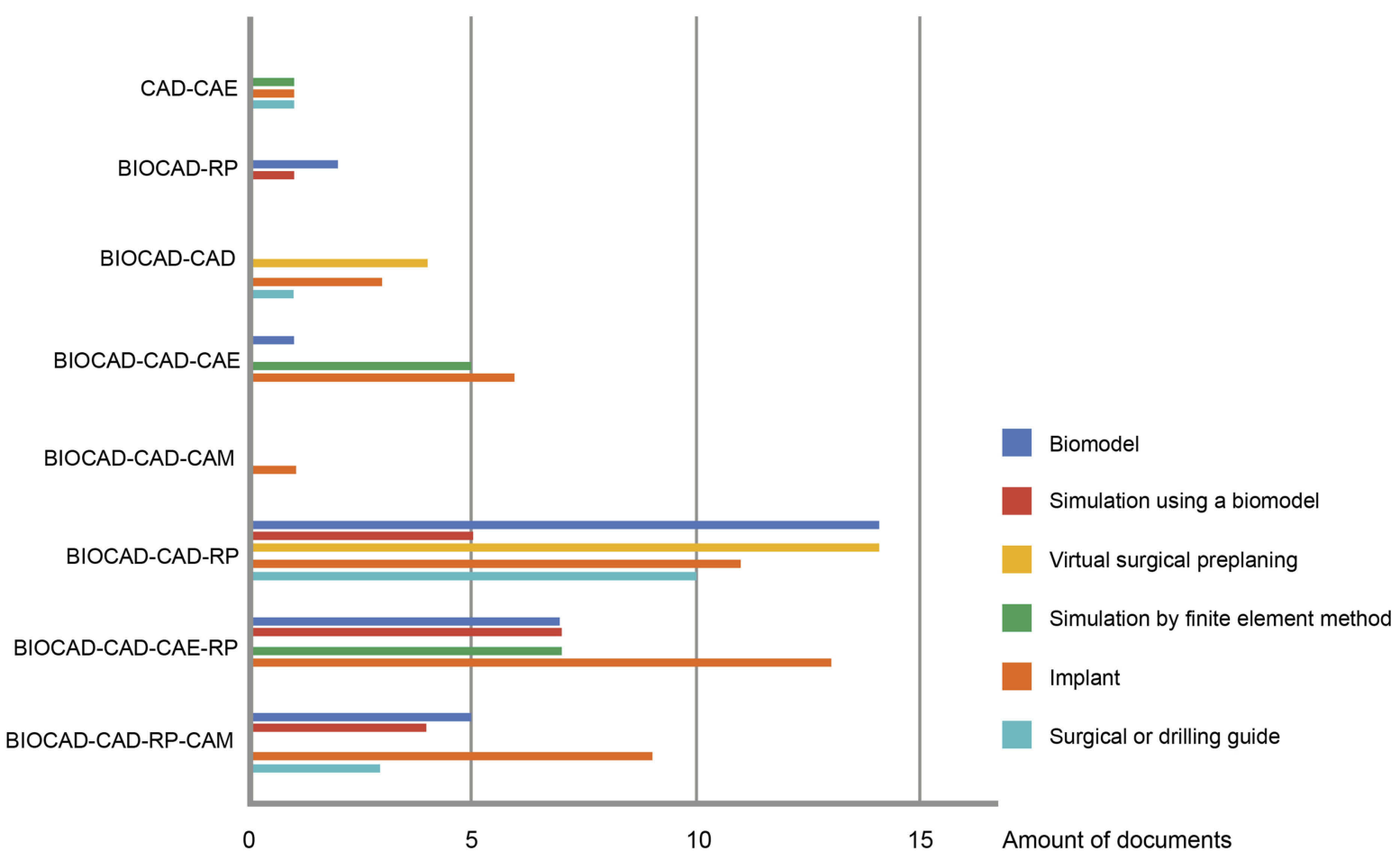

Figure 4 List of medical devices and technology integration models.

Abbreviations: BIOCAD, Biological Computer-aided Design; CAD, Computer-aided Design; CAE, Computer-aided Engineering; CAM, Computer-aided Manufacturing; RP, Rapid Prototyping.

Table I Correlation among specific medical devices. Stronger correlations were among $0.75-0.99$; moderate correlations for $0.4-0.74$; low correlations for values close to 0 ; and inverse correlations for negative values

\begin{tabular}{|l|l|l|l|l|l|l|}
\hline & Biomodel & $\begin{array}{l}\text { Simulation } \\
\text { using a } \\
\text { biomodel }\end{array}$ & $\begin{array}{l}\text { Virtual surgi- } \\
\text { cal } \\
\text { preplanning }\end{array}$ & $\begin{array}{l}\text { Simulation } \\
\text { by finite } \\
\text { element method }\end{array}$ & $\begin{array}{l}\text { Implant } \\
\text { Surgical or } \\
\text { drilling guide }\end{array}$ \\
\hline Biomodel & 1.00 & & & & \\
Simulation using a biomodel & 0.84 & 1.00 & 0.20 & 1.00 & & \\
Virtual surgical preplaning & 0.66 & 0.20 & 1.00 & \\
Simulation by finite element method & 0.21 & 0.57 & 0.46 & 0.52 & 1.00 \\
Implant & 0.85 & 0.86 & 0.91 & -0.31 & 0.57 & 1.00 \\
Surgical or drilling guide & 0.78 & 0.34 & & \\
\hline
\end{tabular}

Integration of BIOCAD + CAD + CAE technologies was reported in 8 cases. $^{2,12,13,15-19}$ In these cases, PSIs were designed and simulations were made for the treatment of maxillofacial, hip, skull, and femur fractures.

The integration of BIOCAD + CAD + CAE + RP was used in 15 cases. The authors ${ }^{11,20-33}$ focused on PSI design, simulating evaluation, and 3D printing. These cases included fractures in the skull, femur, maxillofacial area, and pelvis, as well as the knee, spine, hip, and the orbital area.

The integration of BIOCAD+CAD+RP was used in 27 cases. $^{10,34-54}$ The authors described PSI and RP applications. In most cases, this integration was for fractures of the skull, maxillofacial region, and pelvis.

The BIOCAD + CAD integration was used in 5 cases, ${ }^{55-59}$ while 2 cases were reported using BIOCAD $+\mathrm{RP}$ integration. ${ }^{5,60} \mathrm{CAD}+\mathrm{CAE}$ integration was used in 2 more cases. ${ }^{7,61}$ These binomial models were applied in cases that required the design of custom-made implants, evaluation of standard implants, surgical guides, surgical pre-planning, and simulation with prototype biomodels. These applications were observed in the spine, pelvis, femur and orbital area. 


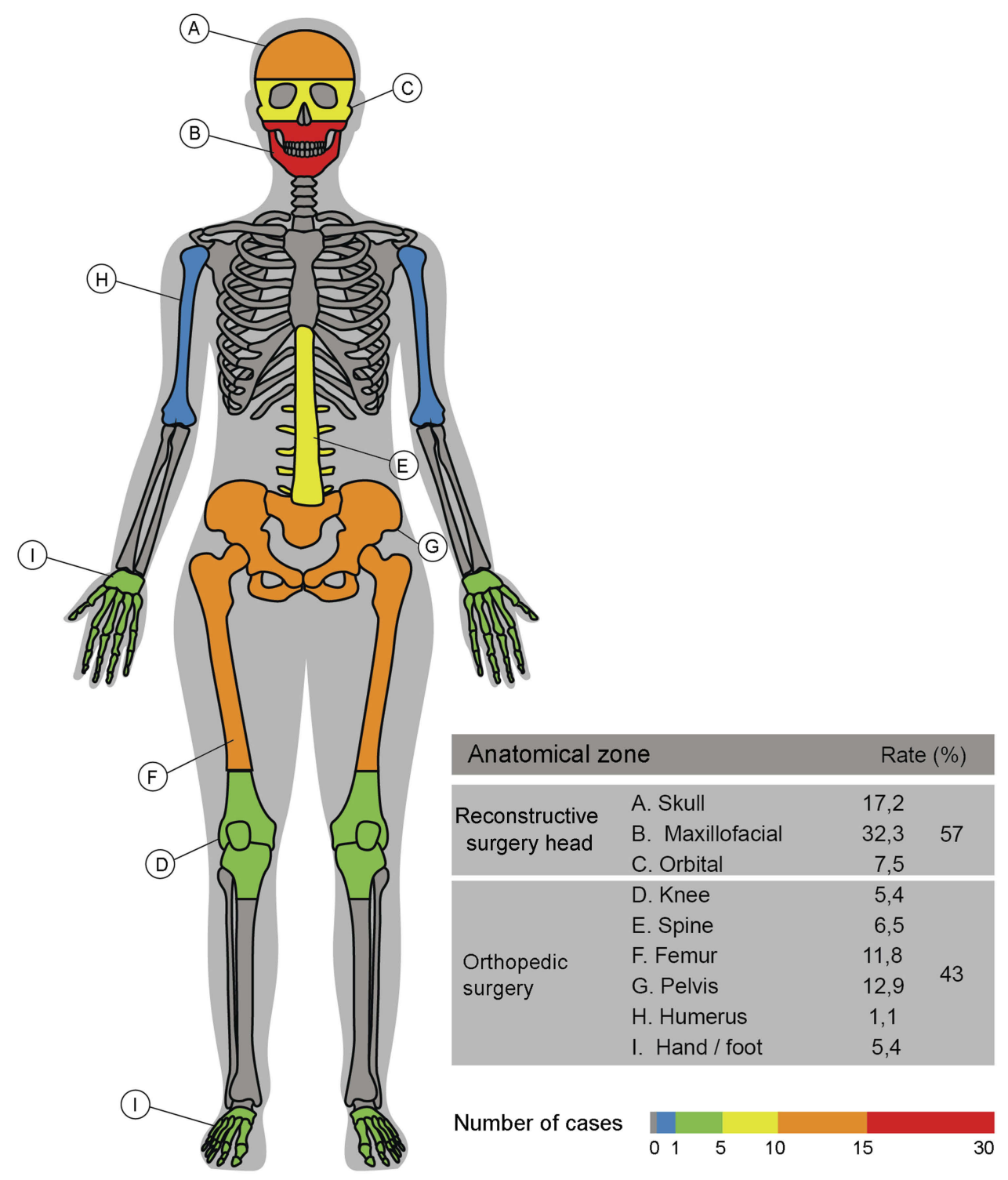

Figure 5 Anatomical regions treated with specific-patient devices.

The integration of BIOCAD $+\mathrm{CAD}+\mathrm{RP}+\mathrm{CAM}$ was observed in 10 cases. $^{3,39,62-69}$ These works focused on 3D printing of biomodels to perform diagnostics, visualize bone defects, and define the surgical approach for cases on the skull and orbital area. In the maxillofacial cases, PSD design was required. Finally, a single implant case for the humerus was identified that used the integration model BIOCAD + CAD + CAM. $^{70}$

\section{Trend analysis}

The ToS web tool allowed citations from the scientific articles to be analyzed, classifying them as classic documents (root), structural documents (trunk), and trend documents (leaves). The trend articles obtained by ToS were analyzed using Nvivo V12 software. As shown in Figure 6, these papers predominantly use CAx software tools for product development.

The trend topics are associated with CAx technologies: data management and quality, product life-cycle management, project data management, human-machine interface, applications of technologies in industries, virtual-physical prototyping, manufacturing simulation, design education, and health applications. As shown in Figure 7, key issues were categorized and organized as a network of nodes.

This analysis provides evidence for strong interest in data integration for the development of digital products through editable files and collaborative work platforms 


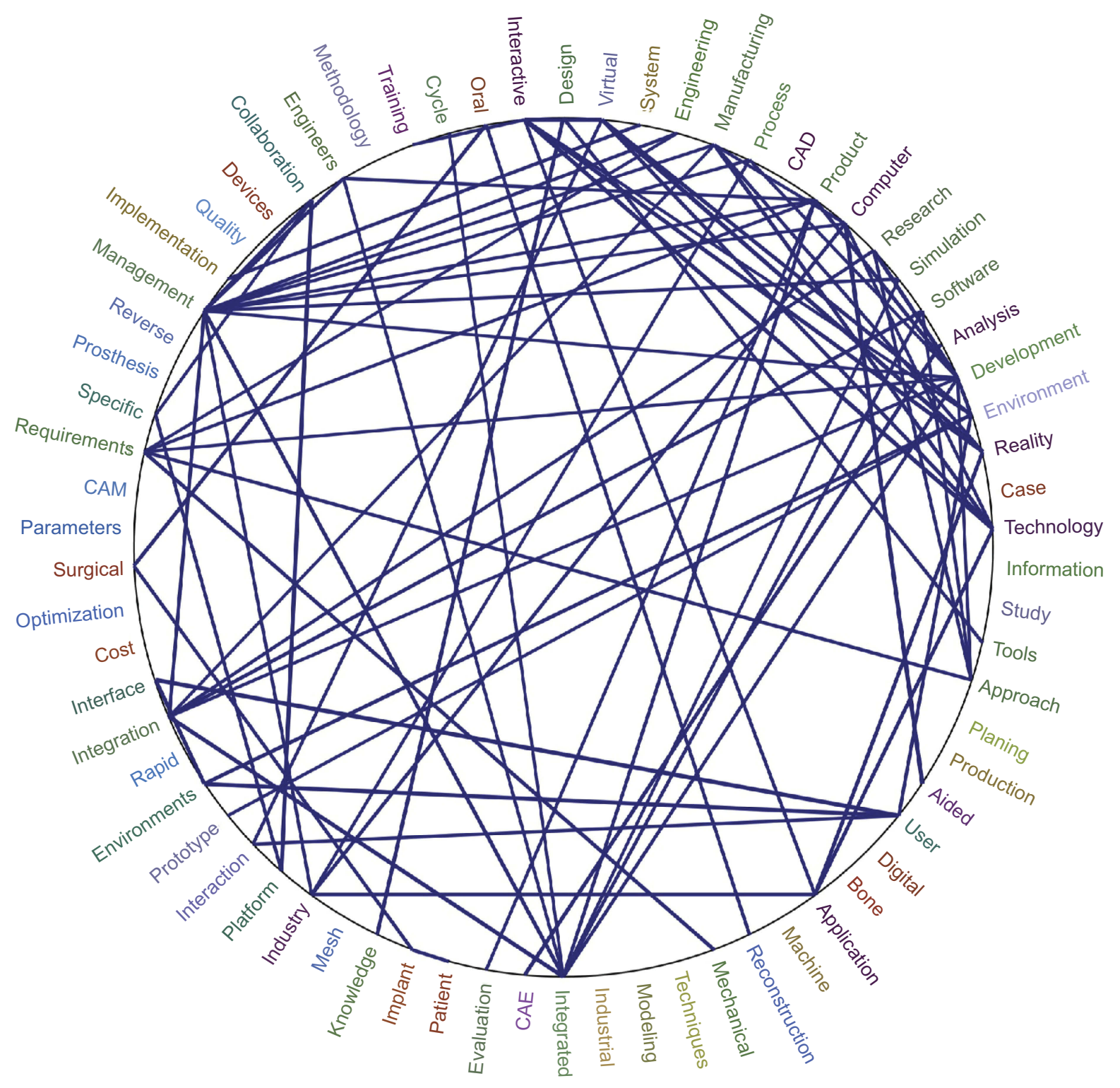

Figure 6 Relationships between the most frequent words in Tree of Science files.

Abbreviations: CAD, Computer-aided Design; CAE, Computer-aided Engineering; CAM, Computer-aided Manufacturing.

connected to interfaces, and interpretation of data among geographically separated researchers. Also of interest was the realization of complex data simulations, monitoring, and control of the design and production phases in real time. ${ }^{71,72}$

These technologies are anticipated to be used in the virtual prototyping of industrial factories, for virtual simulation of manufacturing, for training purposes, teleoperation, ${ }^{73,74}$ virtual immersion from open platforms, ${ }^{75}$ relocation of the productive chain, and industrial machinery. ${ }^{76}$

In addition, research is being conducted into efforts to reduce computational requirements, to improve interoperability during FEM validations by multiple work teams, ${ }^{77}$ and the use of haptic interfaces during CAD/CAE activities. $^{78}$

AM is challenged to manufacture a final product, as well as to establish virtual and physical evaluation methods that enable the determination of the performance of manufactured parts. ${ }^{79}$

Algorithms are being developed to optimize product design by reducing time and costs, ${ }^{80}$ to build decision models for knowledge management, decision making, and virtual verification in the development of complex pieces, ${ }^{81,82}$ to propose creative solutions between 


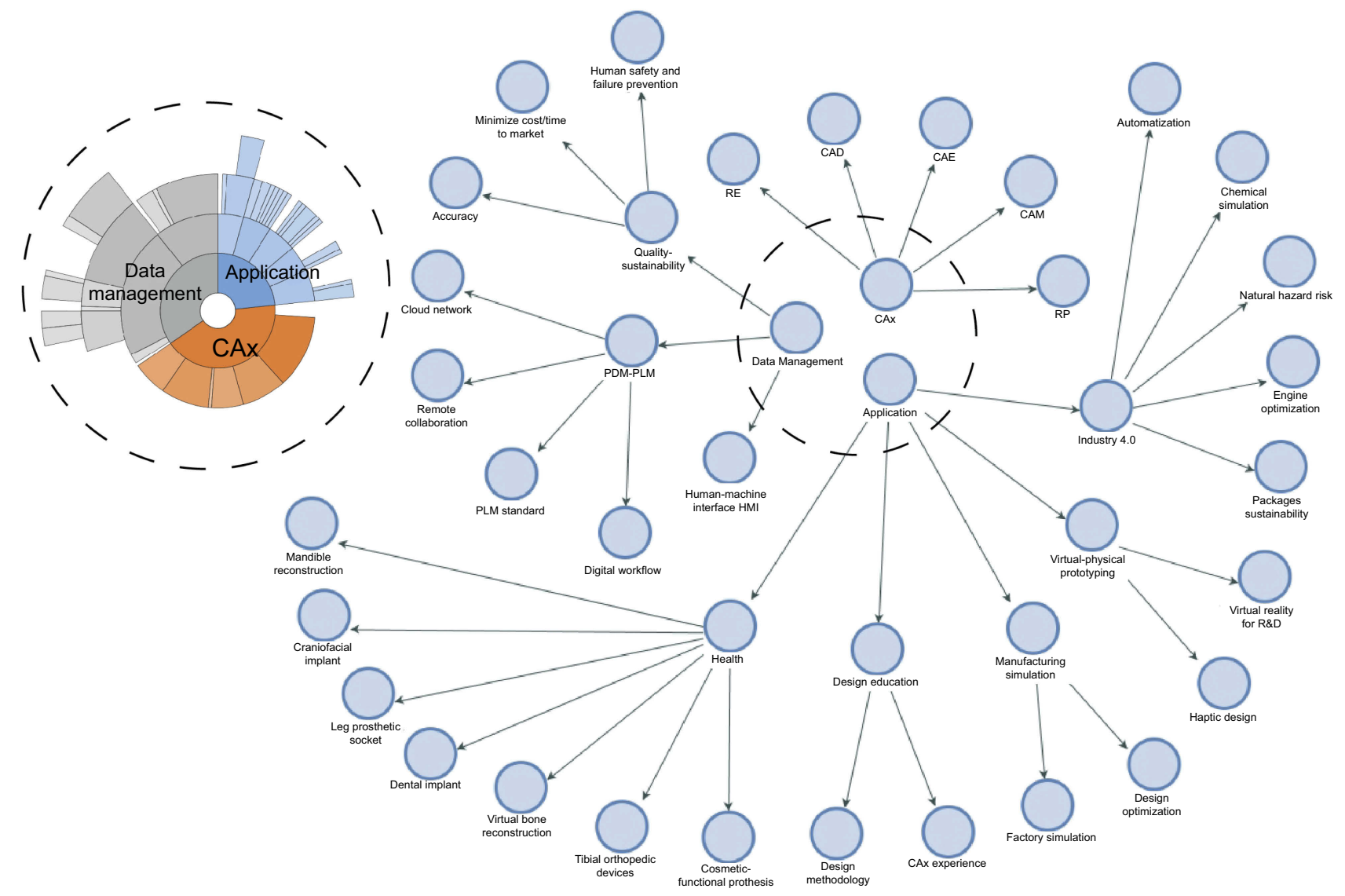

Figure 7 Coding of trends by networking.

Abbreviations: CAD, Computer-aided Design; CAE, Computer-aided Engineering; CAM, Computer-aided Manufacturing; CAx, Computer-Aided Technologies; HMI, Human Machine interface; PDM, Product Data Management; PLM, Product Life-cycle Management; RE, Reverse Engineering; RP, Rapid Prototyping.

interdisciplinary teams, ${ }^{83}$ and to work collaboratively with external groups that use different software during product development. ${ }^{72}$

In the health sector, the documents indicated trends towards the use of CAx technologies for external cosmetic and functional implants of compromised body areas such as the nose ${ }^{84}$ and the ears. ${ }^{85}$

Currently, methods for the direct manufacture of parts for orthopedic rehabilitation are being defined, ${ }^{86}$ optimizing workflows, timelines, and costs for implant development, ${ }^{39}$ craniosynostosis correction, ${ }^{87}$ and mandible reconstruction. ${ }^{88}$

Anthropometric predictive models are being developed for the estimation of cortical zones for FEM analysis, ${ }^{89}$ and for dental implants with precise drill guides. ${ }^{90}$ Strategies have been proposed to control the sources of error in RE such as imaging ${ }^{91}$ or by point cloud. ${ }^{92}$

Collaborative work will be promoted through the development of open virtual design platforms, as stated by Castellano-Smith et $\mathrm{al}^{93}$ using the specific patient modeling method.

\section{Discussion}

\section{Advantages and disadvantages of technological integration}

From the RE + CAD + CAE + RP technologies, other types of personalized products have been generated, such as pre-operative devices adjusted to bone geometry. ${ }^{34,36,37,40-42,45,50,59,61,66,67,94-96}$ These researchers used common practices for product development such as bone reconstruction software and performing alignment and healthy bone symmetry operations on the affected area.

Design requirements were defined based on pre-planning and manufacturing devices with medical grade resin acceptable for final use. PSI models can be created to adjust the shape, geometry, and topology of the device based on the patient's needs, following surgical requirements. ${ }^{39,49,55,64,70}$ Another advantage was the application of CAx tools in surgical pre-planning, predicting bone fixation and reducing surgical risk, manufacturing time for PSD, and time for surgery. ${ }^{32,44,49,54,57,66,68,71,72,77,102,107}$ 
Implementing virtual technologies has advanced strategies such as participatory development, according to Peel et $\mathrm{al},{ }^{39}$ allowing multidisciplinary collaboration between clinical teams (dentists, surgeons, and orthopedists) and development teams (technical engineers and designers). ${ }^{18,65}$ This type of collaborative work ${ }^{98}$ has reduced the gap between user expectations and results and has allowed the manufacturing of complex devices. ${ }^{22,32}$

On the other hand, some disadvantages of technology integration were also identified. Some authors claim that the integration of tools for rapid design and manufacture are economically sustainable, ${ }^{60,61}$ specifically identifying $3 \mathrm{D}$ printing as an accessible, accurate, and profitable resource. ${ }^{2,41,60}$ Other authors claim that barriers such as the high cost of $3 \mathrm{D}$ printing ${ }^{61}$ and increased manufacturing time will keep the implementation of these technologies low. ${ }^{3,10,19,35,60,62,95}$

Problems were also identified related to preoperative explorations, data transfer, and segmentation, decision making for PSD fabrication, ${ }^{39}$ and mistakes in pre-planning that cause irreversible effects on the patient. ${ }^{60} 3 \mathrm{D}$ printed models are not yet suitable for some surgical procedures involving soft tissue anchors. ${ }^{22}$ Implementation of intraoperative navigation systems remains low due to their costs and the level of radiation exposure for both the patient and the medical team. ${ }^{18}$ Also, technical limitations for using specialized software cause surgeons to be dependent on external technicians. ${ }^{95}$

\section{Impact on the quality of patient care}

PSD as a tool after virtual diagnosis provides greater treatment precision, ${ }^{60}$ while $3 \mathrm{D}$ printing helps both physician and patient plan and understand treatment through simulation. ${ }^{99}$ Biomodels and PSD are clinically justified ${ }^{27}$ as they reduce the complexity and improve the precision of diagnosis.

Alloplastic implants are a powerful tool for developing PSDs, especially when working with extensive or complex bone defects. The intraoperative adjustment of plates or meshes for fixation is minimized due to planning, facilitating fast and effective treatment of unilateral or bilateral defects $^{62}$ and functional and aesthetic restoration. ${ }^{49}$ Surgeons and designers can also restore mechanical properties of bone and promote osseointegration, ${ }^{39}$ providing greater stability and minimizing patient risk ${ }^{16}$ due to the accelerated time for effective treatment. ${ }^{97}$

Few complications have been reported during the postoperative period ${ }^{45}$ following neurosurgery, craniomaxillofacial surgery, orthopedic surgery, cardiothoracic surgery, and vascular surgery. ${ }^{22}$

However, patients are exposed to high doses of ionizing radiation during imaging acquisition ${ }^{19}$ because of the use of computed tomography (CT) and cone-beam CT. These images are used to inform treatment, but the radiation may put a patient's health at risk.

The benefits of pre-planning must be weighed against this risk, and children are particularly susceptible to the effects of radiation. ${ }^{61}$ Errors in setting cutting or drilling guides could also have negative functional and aesthetic effects on patients. ${ }^{40}$

\section{Benefits of technology for specialists}

Patient-specific technologies (PSTs) facilitate the interpretation of CT images and reduce uncertainty in diagnosis and treatment. ${ }^{99}$ PSTs also improve fracture characterization and inform the surgical approach, from defining a preoperative plan to producing a final PSD. ${ }^{21,35,37,40,41,43,45,46,48,56,57,65,66,70,95,99}$

Surgical time is reduced because the time spent on repetitive plate fixation adjustments is eliminated or decreased. . $22,38,39,43-45,49,54,57,60,68^{\text {The use of PSTs }}$ allows less experienced surgeons to acquire practical skills safely with less training time. ${ }^{56}$

PSDs are useful in complex and difficult cases, ${ }^{36}$ or in cases with a high risk of complications and unfavorable sequelae for the patient. ${ }^{38,44,45,64}$ Digital and physical resources can improve data visualization during surgery, ${ }^{58}$ and surgical pre-planning expands the utility of intraoperative navigation devices. ${ }^{37,48}$

Although some experienced surgeons prefer manual techniques for conventional surgical pre-planning, this can result in clinical failures ${ }^{60}$ or poor margin resection. ${ }^{40}$ In these cases, surgeons may rely more on their own technical skills than on technologies because the technologies are outside their field of expertise. ${ }^{56}$ Increasing the adoption of PSDs depends on specialist criteria ${ }^{39,48}$ and the availability of technology. ${ }^{10}$

Regarding the quality of the product, important factors included the simplicity of piece positioning, the ease of alignment, surgical guide safety to improve cutting accuracy, and continuous and symmetrical bone restoration results. $^{34}$

The accuracy of position, inclination, and depth of fixation holes and osteotomies compare favorably with those achieved using conventional techniques, reducing collateral damage to nerves and adjacent organs. 


\section{The impact on cost-effectiveness for the health system}

Various authors stated that certainty in the surgical procedure would reduce the cost and time of treatment, decreasing the risks of infections or adverse outcomes. ${ }^{2,34,45}$ Decreased surgery time would improve the quality of the intervention and make the procedure more profitable. ${ }^{37,39,41,48}$

The need for specialized software and hardware to support PSD development requires additional personnel with technical skills in design and product development. ${ }^{37}$ Because these tools require high financial investment for a health care institution, their availability in hospital units is limited and they are more commonly found in laboratories and universities. ${ }^{39}$

The consulted papers rarely analyzed the cost-benefit of these technologies. While the decreased time and cost was mentioned in most of the documents, few compared these technologies with conventional techniques. This type of information is essential to determine whether the use of these techniques can become the standard of care during treatment requiring complex surgery. ${ }^{37}$

Reconstruction planning software and RP technologies are crucial for the design and development of PSDs such as PSIs, guides, and biomodels. Still, this software and technology is relatively expensive, laborious, and multidisciplinary, requiring investment in infrastructure, regulatory compliance, training, and planning time. ${ }^{39}$

\section{Marketing challenges}

CAx in the surgical field can help specialists plan and perform safe, reliable, and precise surgical procedures, ${ }^{10,41,56}$ but the medical sector must diversify its value proposition through the development of new products, services, and processes. ${ }^{57}$ Enabling development units based on PSTs in remote health facilities could create new business models, decrease technological dependence,,$^{35,41}$ and decrease response and delivery times. ${ }^{37}$

Adapting 3D printing for rapid response times and integrating it into standard care protocols could create a new paradigm in surgical planning, ${ }^{10,22,38,41}$ guaranteeing multidisciplinary collaboration between engineering and clinical specialties. ${ }^{37,39}$

Universal implementation of 3D printing depends on the advancement of the technology, availability of freeware resources, and familiarity of surgeons, designers, and engineers with the technique ${ }^{56}$ However, anticipating the demand or number of cases that could use this technique over a certain time period is a complex task. ${ }^{3}$ Despite the recognized time savings and accuracy, there is still a lack of pedagogy to enable PST as a standardized approach. ${ }^{39}$

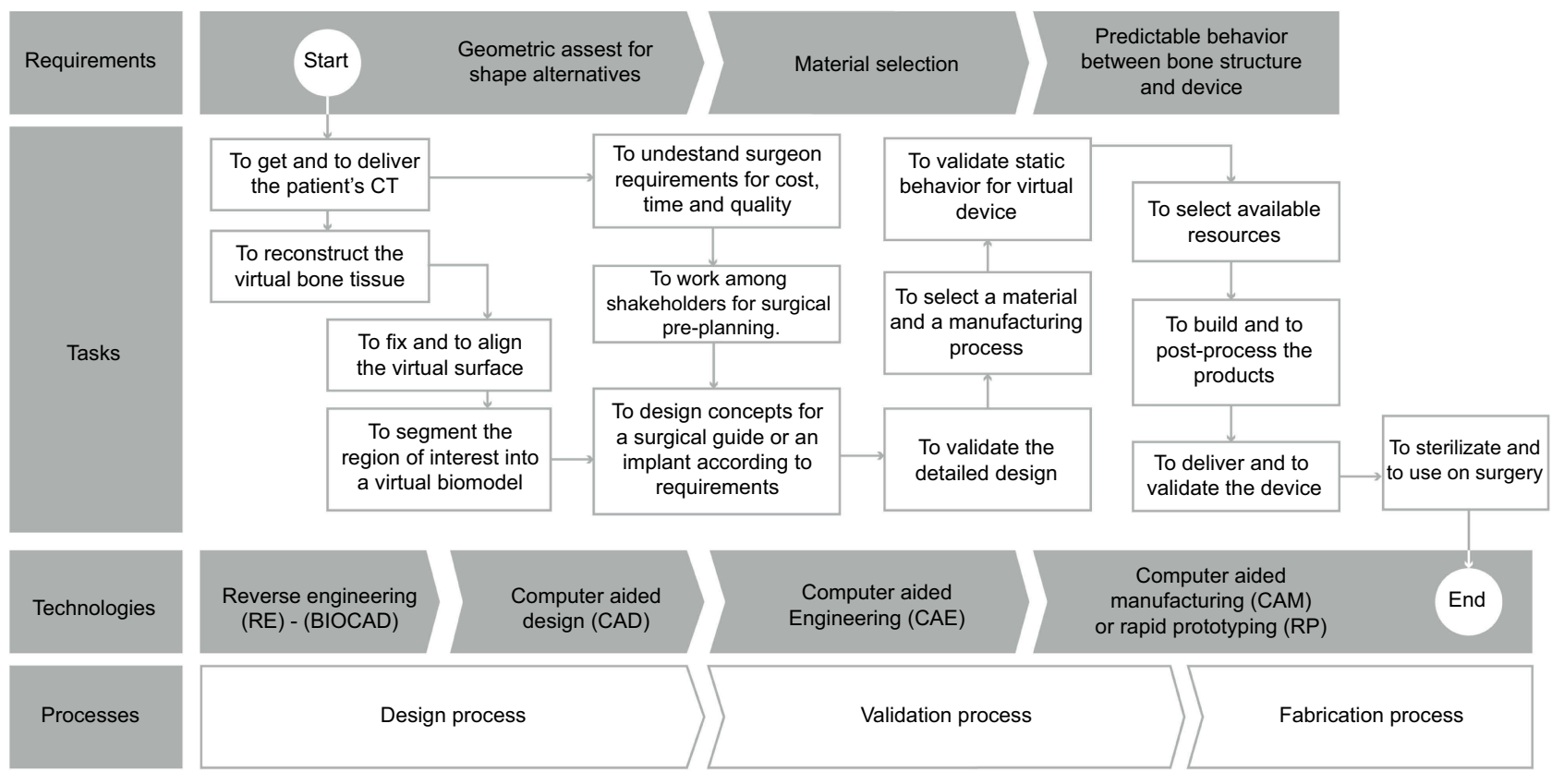

Figure 8 Requirements for design and development of specific medical devices.

Abbreviations: BIOCAD, Biological Computer Aided Design; CT, Computed tomography. 


\section{A consensus in the field of PSTs}

Of the analyzed studies, $80 \%$ used imaging or RE

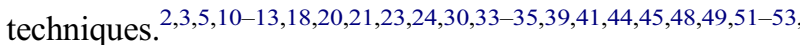
55,56,58,62-64,66-70,94,95,99,100 Fewer articles were identified that used methods to obtain virtual models, measurement references, or definition of contours by $3 \mathrm{D}$ sketching. ${ }^{12,49}$

CAD tools were used in $50 \%$ of the consulted studies, while only $38 \%$ of these studies carried out validations through CAE simulations. The physical prototypes used for diagnosis allow proposed solutions to be visualized and were analyzed in each case study.

In the design phase, iterative verification ${ }^{58}$ was performed to understand deviations between surgical preplanning and the final results. ${ }^{52,96,101}$

The cases analyzed included implant prototypes developed with final materials such as titanium casting, ${ }^{101}$ polymethylmethacrylate casting, ${ }^{46}$ computer numerical controlled machining of titanium alloy Ti6Al4V, ${ }^{13}$ Ti powder sintering using $\mathrm{AM},{ }^{1}$ and $\mathrm{RP}$ of polyether-etherketone. $^{39}$

This analysis identified three basic requirements for the design, evaluation, and prototyping of customized medical devices. A conceptual map of the integration of technologies was outlined from the requirements and the possible design process and is shown in Figure 8.

\section{Conclusion}

The systematic literature review allowed us to understand the different technological integrations that researchers have adopted in the design and development of PSDs such as biomodels, surgical guides, and implants.

In 70 documents, 93 clinical case studies were identified that used interoperable technologies, including RE, CAD, evaluation by FEM simulation, CAE, and RP by AM, SM, or CAM. The analysis showed a relationship between the scope and complexity of the process, the number of stages in the process, and the integration of technologies defined during the process of new product development. The analyzed case studies used technical, scientific, and multidisciplinary strategies to achieve their proposed objectives.

Although there were 26 possible combinations of integration models, only 8 were identified in the literature. The most frequent was the BIOCAD $+\mathrm{CAD}+\mathrm{RP}$ model which was used in $38.6 \%$ of cases, followed by the $\mathrm{BIOCAD}+\mathrm{CAD}+\mathrm{CAE}+\mathrm{RP}$ model which was used in
$21.4 \%$ of cases. This is evidence for the disuse of CAM tools for the manufacture of final devices, replaced in part by AM.

Although the trends indicated increased attention being paid to technologies for process management for data generated during collaborative work, different barriers remain for the incorporation of these technologies in product development related to the cost of resources. It is expected that the benefits of integrated technologies in the health sector will exceed their limitations and that these technologies will become common practice in the treatment of complex pathologies.

\section{Abbreviations list}

AM, Additive Manufacturing; BIOCAD, Biological Computer Aided Design; CAx, Computer-Aided Technologies; CAD, Computer-Aided Design; CAE, Computer-Aided Engineering; CAM, Computer-Aided Manufacturing; CT, Computed tomography; FEM, Finite Element Method; HMI, Human Machine interface; PDM, Product Data Management; PLM, Product Life-cycle Management; PSI, Patient-Specific Implant; PSD, PatientSpecific Devices; PST, Patient-Specific Technologies; RE, Reverse Engineering; RP, Rapid Prototyping; SM, Subtractive Manufacturing; ToS, Tree of Science.

\section{Acknowledgments}

The authors wish to express their gratitude to the following research groups: IINTERFAZ for the industrial design school, GRICES (Research Group in Surgery and Specialties) for the medical school, and INNOTEC (Research Group on Technological Innovation and Knowledge Management), which supports the doctoral program in the electrical engineering, electronics, and telecommunications school. Also, our extended thanks to the VIE 2353 project (Vice-provost for Research and Extension), COLCIENCIAS (Administrative Department of Science, Technology, and Innovation), Universidad Industrial de Santander, and the Santander Government. Funding sources were collected from the Inner Project at Universidad Industrial de Santander and the Administrative Department of Science, Technology and Innovation, COLCIENCIAS.

\section{Author contributions}

All authors contributed towards data analysis, drafting and critically revising the paper, gave final approval of the version to be published, and agreed to be accountable for all aspects of the work. 


\section{Disclosure}

The authors report no conflicts of interest in the present work.

\section{References}

1. Kang H, Long J-P, Urbiel Goldner G-D, Goldstein S-A, Hollister S-J. A paradigm for the development and evaluation of novel implant topologies for bone fixation: implant design and fabrication. $J$ Biomech. 2012;45(13):2241-2247. doi:10.1016/j. jbiomech.2012.06.011

2. Moiduddin K, Darwish S, Al-Ahmari A, ElWatidy S, Mohammad A, Ameen W. Structural and mechanical characterization of custom design cranial implant created using additive manufacturing. Electron $J$ Biotechnol. 2017;29:22-31. doi:10.1016/j. ejbt.2017.06.005

3. Thor A, Palmquist A, Hirsch J-M, Rännar L-E, Dérand P, Omar O. Clinical, morphological, and molecular evaluations of bone regeneration with an additive manufactured osteosynthesis plate. $J$ Craniofac Surg. 2016;27(7):1899-1904. doi:10.1097/ SCS.0000000000002939

4. Balogh Z-J, Reumann M-K, Gruen R-L, et al. Advances and future directions for management of trauma patients with musculoskeletal injuries. Lancet. 2012;380(9847):1109-1119. doi:10.1016/S01406736(12)60991-X

5. Bruns J, Habermann C-R, Rüther W, Delling D. The use of CT derived solid modelling of the pelvis in planning cancer resections. Eur J Surg Oncol. 2010;36(6):594-598. doi:10.1016/j.ejso.2009. 11.005

6. Robiony M, Salvo I, Costa F, et al. Accuracy of virtual reality and stereolithographic models in maxillo-facial surgical planning. $J$ Craniofac Surg. 2008;19(2):482-489. doi:10.1097/SCS.0b013e3 $1814 \mathrm{fb} 5 \mathrm{c} 1$

7. Senalp A-Z, Kayabasi O, Kurtaran H. Static, dynamic and fatigue behavior of newly designed stem shapes for hip prosthesis using finite element analysis. Mater Des. 2007;28(5):1577-1583. doi:10.1016/j.matdes.2006.02.015

8. Rama-Murthy S, Mani M. Design for sustainability: the role of CAD. Renew Sustain Energy Rev. 2012;16(6):4247-4256. doi:10.1016/j.rser.2012.03.009

9. Gujarathi G-P, Ma Y-S. Parametric CAD/CAE integration using a common data model. J Manuf Syst. 2011;30(3):118-132. doi:10.1016/j.jmsy.2011.01.002

10. Bagaria V, Deshpande S, Rasalkar -D-D, Kuthe A, Paunipagar B$\mathrm{K}$. Use of rapid prototyping and three-dimensional reconstruction modeling in the management of complex fractures. Eur J Radiol. 2011;80(3):814-820. doi:10.1016/j.ejrad.2010.10.007

11. Parthasarathy J, Starly B, Raman S. A design for the additive manufacture of functionally graded porous structures with tailored mechanical properties for biomedical applications. J Manuf Process. 2011;13(2):160-170. doi:10.1016/j.jmapro.2011.01.004

12. Griza S, Kwietniewski C, Tarnowski G-A, et al. Fatigue failure analysis of a specific total hip prosthesis stem design. Int J Fatigue. 2008;30:1325-1332. doi:10.1016/j.ijfatigue.2007.11.005

13. Ojeda CJ, Carlín J, Saavedra P, Moscol G, Almeida J. Diseño, Análisis por $\mathrm{Ct}$ y construcción por $\mathrm{CAD} / \mathrm{CAM}$ de endoprótesis femoral personalizada: caso de una paciente con subluxacion congénia. $8{ }^{\circ}$ Congreso Iberoamericano de Ingeniería Mecánica; 2007; Cusco. doi:10.1094/PDIS-91-4-0467B

14. Thompson R-G. Anatomics 3d-printed Titanium Implants from Head to Heel. Cambridge: Woodhead Publishing; 2018. doi:10.1016/b978-0-12-812456-7.00010-x

15. Faegh S, Müftü S. Load transfer along the bone-dental implant interface. $J$ Biomech. 2010;43(9):1761-1770. doi:10.1016/j. jbiomech.2010.02.017
16. Ammar -H-H, Ngan P, Crout R-J, Mucino V-H, Mukdadi O-M. Three-dimensional modeling and finite element analysis in treatment planning for orthodontic tooth movement. Am J Orthod Dentofac Orthop. 2004;139(1):e59-e71. doi:10.1016/j. ajodo.2010.09.020

17. Perestrelo P, Bártolo P, Torres M-P, Noritomi P, Silva J. Human cranium biomechanical simulation. High Value Manufacturing: Advanced Research in Virtual and Rapid Prototyping; 2013:531536.

18. Mircheski I, Gradišar M. 3D finite element analysis of porous Ti-based alloy prostheses. Comput Methods Biomech Biomed Engin. 2016;19(14):1531-1540. doi:10.1080/ 10255842.2016.1167881

19. Thevenot J, Koivumäki J, Kuhn V, Eckstein F, Jämsä T. A novel methodology for generating 3D finite element models of the hip from 2D radiographs. $J$ Biomech. 2014;47(2):438-444. doi:10.1016/j.jbiomech.2013.11.004

20. Borghi A, Rodgers Ã, Schievano Ã, et al. Proof of concept study for the design, manufacturing, and testing of a patient-specific shape memory device for treatment of unicoronal craniosynostosis. J Craniofac Surg. 2017;00(00):1-4. doi:10.1097/ SCS.0000000000004025

21. Malyala S-K, Alwala A-M. A 3D printed osseointegrated combined jaw and dental implant prosthesis - a case study. Rapid Prototyp J. 2016;23(6):1164-1169.

22. Provaggi E, Leong -J-J-H, Kalaskar D-M. Applications of 3D printing in the management of severe spinal conditions. 2 Proc IMechE Part H: J Engineering in Medicine. 2017;231: 471-486. doi: $10.1177 / 0954411916667761$

23. Doerfler H-M, Huempfner-hierl H, Kruber D, Schulze P, Hierl T. Template-based orbital wall fracture treatment using statistical shape analysis. J Oral Maxillofac Surg. 2017;75(7):1475.e11475.e8. doi:10.1016/j.joms.2017.03.048

24. Iqbal T, Shi L, Wang L, et al. Development of finite element model for customized prostheses design for patient with pelvic bone tumor. Proc IMechE Part H: J Engineering in Medicine. 2017;231:525-533. doi:10.1177/0954411917692009

25. Yosibash Z, Katz A, Milgrom C. Toward verified and validated FE simulations of a femur with a cemented hip prosthesis. Med Eng Phys. 2013;35(7):978-987. doi:10.1016/j.medengphy.2012. 09.007

26. El Halabi F, Rodriguez JF, Rebolledo L, Hurtós E, Doblaré M. Mechanical characterization and numerical simulation of polyetherether-ketone (PEEK) cranial implants. J Mech Behav Biomed Mater. 2011;4(8):1819-1832. doi:10.1016/j.jmbbm.2011.05.039

27. Jun Y, Choi K. Design of patient-specific hip implants based on the 3D geometry of the human femur. Adv Eng Softw. 2010;41(4):537547. doi:10.1016/j.advengsoft.2009.10.016

28. Dhakshyani R, Nukman Y, Azuan A-O-N. FDM models and FEA in dysplastic hip. Rapid Prototyp J. 2012;18(3):215-221. doi:10.1108/13552541211218144

29. Kluess D, Souffrant R, Mittelmeier W, Wree A, Schmitz K-P, Bader R. A convenient approach for finite-element-analyses of orthopaedic implants in bone contact: modeling and experimental validation. Comput Methods Programs Biomed. 2009;95(1):23-30. doi:10.1016/j.cmpb.2009.01.004

30. Isaza J-F. Prototipaje rápido de estructuras craneofaciales. Ing $Y$ Cienc. 2008;4(8):27-43.

31. Harrysson O-L-A, Cansizoglu O, Marcellin-Little D-J, Cormier DR, West H-A. Direct metal fabrication of titanium implants with tailored materials and mechanical properties using electron beam melting technology. Mater Sci Eng C. 2008;28(3):366-373. doi:10.1016/j.msec.2007.04.022

32. Sun W, Starly B, Nam J, Darling A. Bio-CAD modeling and its applications in computer-aided tissue engineering. Comput Des. 2005;37(11):1097-1114. doi:10.1016/j.cad.2005.02.002 
33. Hosni Y-A. Contribution of CAD-CAM and reverse engineering technology to the biomedical field. In: Current Advances in Mechanical Design and Production VII. Cairo: Pergamon; 2000:491-499.

34. Azimifar F, Hassani K, Saveh A-H, Tabatabai-Ghomshe F. A low invasiveness patient's specific template for spine surgery. Proc IMechE Part H J Eng Med. 2017;231(2):143-148. doi:10.1177/ 0954411916682770

35. Msallem B, Jaquiéry $\mathrm{C}$, Thieringer F, Jaquiéry $\mathrm{C}$, Thieringer $\mathrm{F}$. Craniofacial reconstruction by a cost-efficient template-based process using 3D printing. Plast Reconstr Surg Glob Open. 2017;5 (11):1-5. doi:10.1097/GOX.0000000000001582

36. Schweizer A, Mauler F, Vlachopoulos L, Nagy L, Fürnstahl P. Computer-assisted 3-dimensional reconstructions of scaphoid fractures and nonunions with and without the use of patient-specific guides: early clinical outcomes and postoperative assessments of reconstruction accuracy. J Hand Surg Am. 2016;41(1):59-69. doi:10.1016/j.jhsa.2015.10.009

37. Kalamaras M, McEniery P, Thorn K, Bindra R. Rapid prototyping and $3 \mathrm{D}$ modeling of osteotomy jigs and drill guides in hand and wrist surgery. Tech Orthop. 2016;31(3):164-171. doi:10.1097/ BTO.0000000000000185

38. Singhal A-J, Shetty V, Bhagavan K-R, et al. Improved surgery planning using 3-D printing: a case study. Indian J Surg. 2016;78 (April):100-104. doi:10.1007/s12262-015-1326-4

39. Peel S, Bhatia S, Eggbeer D, Morris D-S, Hayhurst C. Evolution of design considerations in complex craniofacial reconstruction using patient-specific implants. Proc IMechE Part H: J Engineering in Medicine. 2017;231:509-524. doi:10.1177/0954411916681346

40. Weijs W-L-J, Coppen C, Schreurs R, et al. Accuracy of virtually 3D planned resection templates in mandibular reconstruction. $J$ Craniomaxillofac Surg. 2016;44(11):1828-1832. doi:10.1016/j. jcms.2016.08.024

41. Cartiaux O, Paul L, Francq B, Banse X, Docquier P-L. Improved accuracy with $3 \mathrm{D}$ planning and patient-specific instruments during simulated pelvic bone tumor surgery. Ann Biomed Eng. 2014;42 (1):205-213. doi:10.1007/s10439-013-0890-7

42. Ma T, Xu Y-Q, Cheng Y-B, et al. A novel computer-assisted drill guide template for thoracic pedicle screw placement: A cadaveric study. Arch Orthop Trauma Surg. 2012;132(1):65-72. doi:10.1007/ s00402-011-1383-5

43. Wang G, Li J, Khadka A, Hsu Y, Li W, Hu J. CAD/CAM and rapid prototyped titanium for reconstruction of ramus defect and condylar fracture caused by mandibular reduction. Oral Surg Oral Med Oral Pathol Oral Radiol. 2012;113(3):356-361. doi:10.1016/j. tripleo.2011.03.034

44. Rotaru H, Stan H, Florian IS, et al. Cranioplasty with custom-made implants: analyzing the cases of 10 patients. J Oral Maxillofac Surg. 2012;70(2):e169-e176. doi:10.1016/j.joms.2011.09.036

45. Mazzoni S, Marchetti C, Sgarzani R, Cipriani R, Scotti R, Ciocca L. Prosthetically guided maxillofacial surgery: evaluation of the accuracy of a surgical guide and custom-made bone plate in oncology patients after mandibular reconstruction. Plast Reconstr Surg. 2013;131(6):1376-1385. doi:10.1097/PRS.0b01 3e31828bd6b0

46. Soler R, Moreno J-L, Cabrera C. Implante craneano individual de gran volumen en polimetilmetacrilato de metilo a partir de un prototipo rápido. Reporte de un caso. Odontoestomatologia. 2011;13(17):26-36.

47. Mustafa SF, Evans PL, Bocca A, Patton DW, Sugar AW, Baxter PW. Customized titanium reconstruction of post-traumatic orbital wall defects: a review of 22 cases. Int J Oral Maxillofac Surg. 2011;40(12):1357-1362. doi:10.1016/j.ijom.2011.04.020

48. Zhang Y-Z, Lu S, Yang Y, Xu Y-Q, Li Y-B, Pei G-X. Design and primary application of computer-assisted, patient-specific navigational templates in metal-on-metal hip resurfacing arthroplasty. J Arthroplasty. 2011;26(7):1083-1087. doi:10.1016/j.arth.2010.08.004
49. Casallo C-A, Tantas G, Pineda R-A. Craneoplastía con implante de polieteretercetona diseñado por computadora. Acta Med Per. 2010;27(3):193-195.

50. Kunz M, Rudan JF, Xenoyannis GL, Ellis RE. Computer-assisted hip resurfacing using individualized drill templates. J Arthroplasty. 2010;25(4):600-606. doi:10.1016/j.arth.2009.03.023

51. White D, Chelule K-L, Seedhom B-B. Accuracy of MRI vs CT imaging with particular reference to patient specific templates for total knee replacement surgery. Int J Med Robot Comput Assist Surg. 2008;4(August):224-231. doi:10.1002/rcs

52. Dai K-R, Yan M-N, Zhu Z-A, Sun Y-H. Computer-aided custommade hemipelvic prosthesis used in extensive pelvic lesions. $J$ Arthroplasty. 2007;22(7):981-986. doi:10.1016/j.arth.2007.05.002

53. Gibson I, Cheung LK, Chow SP, et al. The use of rapid prototyping to assist medical applications. Rapid Prototyping Journal. 2006;12 (1):53-58. doi:10.1108/13552540610637273.

54. Heissler E, Fischer F, Lehmann S-B-T, et al. Custom-made cast titanium implants produced with CAD/CAM for the reconstruction of cranium defects. Int J Oral Maxillofac Surg. 1998;27(5):334338.

55. Owen B-D, Christensen G-E, Reinhardt J-M, Ryken TC. Rapid prototype patient-specific drill template for cervical pedicle screw placement. Comput Aided Surg. 2007;12(5):303-308. doi:10.3109/ 10929080701662826

56. Hu Y, Li H, Qiao G, Liu H, Ji A, Ye F. Computer-assisted virtual surgical procedure for acetabular fractures based on real CT data. Injury. 2011;42(10):1121-1124. doi:10.1016/j.injury.2011.01.014

57. Défossez H-J-P, Serhan H. Managing design excellence tools during the development of new orthopaedic implants. J Biomech Eng. 2014;135(November 2013):114506-1/11. doi:10.1115/1.4025323

58. Werner A, Lechniak Z, Skalski K, Ke K. Design and manufacture of anatomical hip joint endoprostheses using CAD/CAM systems. $J$ Mater Process Technol. 2000;107:181-186. doi:10.1016/S09240136(00)00682-8

59. Bauer A-S, Storelli D-A-R, Sibbel S-E, Mccarroll H-R, Lattanza -L-L. Preoperative computer simulation and patient-specific guides are safe and effective to correct forearm deformity in children. $J$ Pediatr Orthop. 2017;37(7):504-510. doi:10.1097/BPO.0000000 000000673

60. Chul Y, Shik W, Park T, Woo J, Koh K-S, Suk T. The accuracy of patient specific implant prebented with 3D-printed rapid prototype model for orbital wall reconstruction. J Craniomaxillofac Surg. 2017;45(6):928-936. doi:10.1016/j.jcms.2017.03.010

61. Barone S, Paoli A, Razionale A-V, Savignano R. Computer-aided modelling to simulate the biomechanical behaviour of customised orthodontic removable appliances. Int $J$ Interact Des Manuf. 2016;10(4):387-400. doi:10.1007/s12008-014-0246-z

62. Rudman K, Hoekzema C, Rhee J. Computer-assisted innovations in craniofacial surgery. Facial Plast Surg. 2011;27(4):358-365. doi:10.1055/s-0031-1283054

63. Kozakiewicz M, Elgalal M, Walkowiak B, Stefanczyk L. Technical concept of patient-specific, ultrahigh molecular weight polyethylene orbital wall implant. J Craniomaxillofac Surg. 2013;41 (4):282-290. doi:10.1016/j.jcms.2012.10.007

64. Salmi M, Tuomi J, Paloheimo K-S, et al. Patient-specific reconstruction with 3D modeling and DMLS additive manufacturing. Rapid Prototyp J. 2012;18(3):209-214. doi:10.1108/13552541211 218126

65. Rohner D, Guijarro-Martínez R, Bucher P, Hammer B. Importance of patient-specific intraoperative guides in complex maxillofacial reconstruction. J Craniomaxillofac Surg. 2013;41(5):382-390. doi:10.1016/j.jcms.2012.10.021

66. Kraeima J, Jansma J, Schepers R-H. Splintless surgery: does patient-specific CAD-CAM osteosynthesis improve accuracy of Le Fort I osteotomy? Br J Oral Maxillofac Surg. 2016;54 (10):1085-1089. doi:10.1016/j.bjoms.2016.07.007 
67. Suojanen J, Leikola J, Stoor P. The use of patient-specific implants in orthognathic surgery: A series of 32 maxillary osteotomy patients. $J$ Craniomaxillofac Surg. 2016;44(12):1913-1916. doi:10.1016/j.jcms.2016.09.008

68. Probst F-A, Metzger M, Ehrenfeld M, Cornelius C-P. Computerassisted designed and manufactured procedures facilitate the lingual application of mandible reconstruction plates. J Oral Maxillofac Surg. 2016;74(9):1879-1895. doi:10.1016/j.joms.2016.03.015

69. Maini L, Sharma A, Jha S, Tiwari A. Three-dimensional printing and patient-specific pre-contoured plate : future of acetabulum fracture fixation? Eur J Trauma Emerg Surg. 2018;44:215-224. doi:10.1007/s00068-016-0738-6

70. Rashid -M-M, Husain K-N. Geometrical model creation methods for human humerus bone and modified cloverleaf plate. J Sci Ind Res. 2017;76(October):631-639.

71. Choi S, Jung K, Noh S-D. Virtual reality applications in manufacturing industries: past research, present findings, and future directions. Concurr Eng Res Appl. 2015;23(1):40-63. doi:10.1177/ $1063293 X 14568814$

72. Jonovic V-M, Ma L, Guerra-Zubiaga D-A, Tomovic -M-M. Early problems identification in collaborative engineering with different product data modelling standards. Int J Comput Integr Manuf. 2015;28(11):1155-1166. doi:10.1080/0951192X.2014.961961

73. Bourne D, Corney J, Gupta S-K. Recent advances and future challenges in automated manufacturing planning. J Comput Inf Sci Eng. 2011;11(2):021006. doi:10.1115/1.3593411

74. Vergnano A, Berselli G, Pellicciari M. Interactive simulationbased-training tools for manufacturing systems operators: an industrial case study. Int J Interact Des Manuf. 2017;11(4):785-797. doi:10.1007/s12008-016-0367-7

75. Calvo I, López F, Zulueta E, González-Nalda P. Towards a methodology to build virtual reality manufacturing systems based on free open software technologies. Int J Interact Des Manuf. 2017;11 (3):569-580. doi:10.1007/s12008-016-0311-x

76. Lindskog E, Vallhagen J, Johansson B. Production system redesign using realistic visualisation. Int J Prod Res. 2017;55(3):858-869. doi:10.1080/00207543.2016.1218085

77. Song I-H, Yang J, Jo H, Choi S. Development of a lightweight CAE middleware for CAE data exchange. Int J Comput Integr Manuf. 2009;22(9):823-835. doi:10.1080/09511920902866088

78. Talaba D, Antonya C. Virtual prototyping of mechanical systems with tool mediated haptic feedback. Eng Comput. 2012;30(4):569582. doi:10.1007/s00366-012-0301-y

79. Vaughan M-R, Crawford R-H. Effectiveness of virtual models in design for additive manufacturing: A laser sintering case study. Rapid Prototyp J. 2013;19(1):11-19. doi:10.1108/13552541311292682

80. Cui D, Feng G, Zhou P, Zhang Y. Parametric design-based multiobjective optimisation for high-pressure turbine disc. Int J Prod Res. 2017;55(17):4847-4861. doi:10.1080/00207543.2016.1259669

81. Durupt A, Remy S, Ducellier G. Knowledge-based reverse engineering - an approach for reverse engineering of a mechanical part. J Comput Inf Sci Eng. 2010;10(4):044501. doi:10.1115/1.3482059

82. Mejía-Gutiérrez R, Carvajal-Arango R. Design verification through virtual prototyping techniques based on systems engineering. Res Eng Des. 2017;28(4):477-494. doi:10.1007/s00163-016-0247-y

83. Chulvi V, Mulet E, Felip F, García-García C. The effect of information and communication technologies on creativity in collaborative design. Res Eng Des. 2017;28(1):7-23. doi:10.1007/s00163-016-0227-2

84. Ciocca L, Fantini M, Crescenzio F, Persiani F, Scotti R. New protocol for construction of eyeglasses-supported provisional nasal prosthesis using CAD/CAM techniques. J Rehabil Res Dev. 2010;47(7):595. doi:10.1682/jrrd.2009.11.0189

85. De-Crescenzio F, Fantini M, Ciocca L, Persiani F, Scotti R. Design and manufacturing of ear prosthesis by means of rapid prototyping technology. Proc IMechE Vol. 225 Part H: J. Engineering in Medicine. 2011;225:296-302. doi:10.1243/09544119JEIM856
86. Cronskär M, Rännar L-E, Bäckström M. Implementation of digital design and solid free-form fabrication for customization of implants in trauma orthopaedics. J Med Biol Eng. 2012;32(2):9196. doi: $10.5405 /$ jmbe. 883

87. Seruya M, Borsuk D-E, Khalifian S, Carson B-S, Dalesio N-M, Dorafshar A-H. Computer-aided design and manufacturing in craniosynostosis surgery. J Craniofac Surg. 2013;24(4):1100-1105. doi:10.1097/SCS.0b013e31828b7021

88. Zhou L-B, Shang H-T, He L-S, et al. Accurate reconstruction of discontinuous mandible using a reverse engineering/computeraided design/rapid prototyping technique: A preliminary clinical study. J Oral Maxillofac Surg. 2010;68(9):2115-2121. doi:10. 1016/j.joms.2009.09.033

89. Davis M-L, Vavalle N-A, Stitzel J-D, Gayzik F-S. A technique for developing CAD geometry of long bones using clinical CT data. Med Eng Phys. 2015;37(11):1116-1123. doi:10.1016/j.medengphy.2015. 08.014

90. Dawood A, Purkayastha S, Patel S, Mackillop F, Tanner S. Microtechnologies in implant and restorative dentistry: A stroll through a digital dental landscape. Proceedings of the Institution of Mechanical Engineers, Part H: Journal of Engineering in Medicine. 2010;224:789-796. doi:10.1243/09544119JEIM660

91. Martorelli M, Ausiello P, Morrone R. A new method to assess the accuracy of a cone beam computed tomography scanner by using a non-contact reverse engineering technique. J Dent. 2014;42 (4):460-465. doi:10.1016/j.jdent.2013.12.018

92. Pathak V-K, Nayak C, Singh A-K, Chaudhary H. A virtual reverse engineering methodology for accuracy control of transtibial prosthetic socket. Biomed Eng Appl Basis Commun. 2016;28 (5):1650037-1/9. doi:10.4015/s101623721650037x

93. Castellano-Smith A-D, Hartkens T, Schnabel J, et al. Constructing patient-specific models for correcting intraoperative brain deformation. Lect Notes Comput Sci. 2001;2208:1091-1098. doi:10.1007/3540-45468-3 130

94. Merc M, Drstvensek I, Vogrin M, Brajlih T, Recnik G. A multilevel rapid prototyping drill guide template reduces the perforation risk of pedicle screw placement in the lumbar and sacral spine. Arch Orthop Trauma Surg. 2013;133(7):893-899. doi:10.1007/ s00402-013-1755-0

95. Du H, Tian -X-X, Li T, et al. Use of patient-specific templates in hip resurfacing arthroplasty: experience from sixteen cases. Int Orthop. 2013;37(5):777-782. doi:10.1007/s00264-013$1842-4$

96. Oka K, Murase T, Moritomo H, Yoshikawa H. Corrective osteotomy for malunited both bones fractures of the forearm with radial head dislocations using a custom-made surgical guide: two case reports. J Shoulder Elb Surg. 2012;21(10):e1-e8. doi:10.1016/j. jse.2012.05.035

97. Moiduddin K, Anwar S, Ahmed N, Ashfaq M, Al-ahmari A. Computer assisted design and analysis of customized porous plate for mandibular reconstruction. IRBM. 2017;38(2):78-89. doi:10.1016/j.irbm.2017.01.003

98. Romero A, Álvarez M, Guevera Galindo O. Biomodelacion parametrizada como solucion a los problemas de fracturas atipicas y malformaciones óseas en cadera [Biomodeling parameterized as a solution to problems of atopic fractures and bone malformations in the hip]. Presented at the 8 vo Congreso Iberoamericano de Ingeniería Mecánica; Cusco, Peru; October 25, 2007. doi:10.1094/PDIS-91-4-0467B. Available from: http://congreso. pucp.edu.pe/cibim8/pdf/03/03-07.pdf. Accessed July 30, 2019. Spanish.

99. Starosolski Z-A, Kan J-H, Rosenfeld S-D, Krishnamurthy R, Annapragada A. Application of 3-D printing (rapid prototyping) for creating physical models of pediatric orthopedic disorders. Pediatr Radiol. 2014;44(2):216-221. doi:10.1007/s00247-0132788-9 
100. Kluess D, Zietz C, Hauck S, Bader R, Schmitz K-P, Mittelmeier W. Modularity of a new cementless acetabular revision cup system based on research of the anatomic variability of the pelvis. Biomed Tech (Berl). 2010;55(4):229-235. doi:10.1515/BMT.2010.033

101. Singare S, Dichen L, Bingheng L, Yanpu L, Zhenyu G, Yaxiong L. Design and fabrication of custom mandible titanium tray based on rapid prototyping. Med Eng Phys. 2004;26(8):671-676. doi:10.1016/j.medengphy.2004.06.001
102. Isaza JF, Correa S. Metodología para la reconstrucción 3D de estructuras craneofaciales y su utilización en el método de elementos finitos. Ing Y Cienc. 2008;4(7):129-149.

103. Meline T. Selecting studies for systematic review: inclusion and exclusion criteria. Contemp Issues Commun Sci Disord. 2006;33:21-27. 


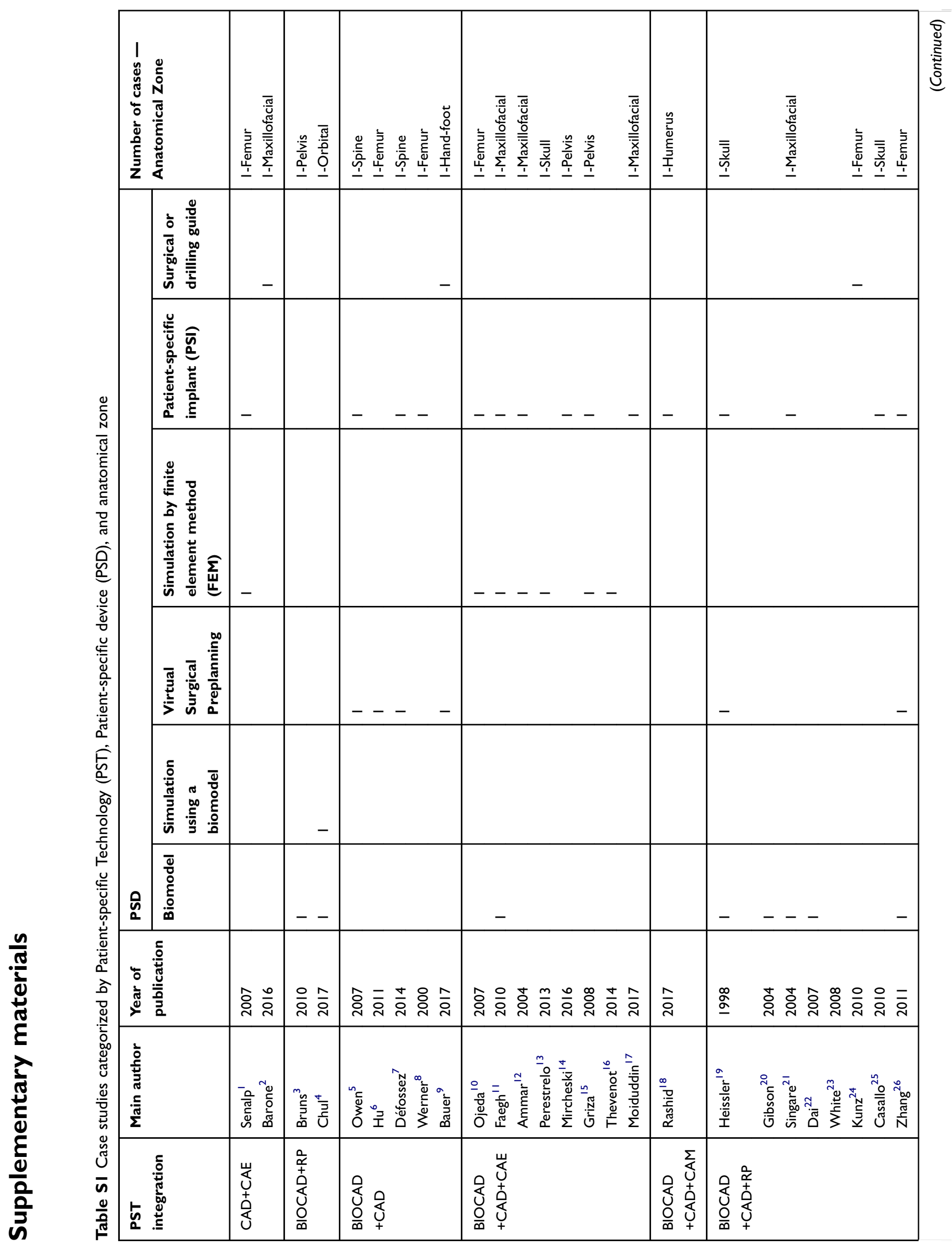




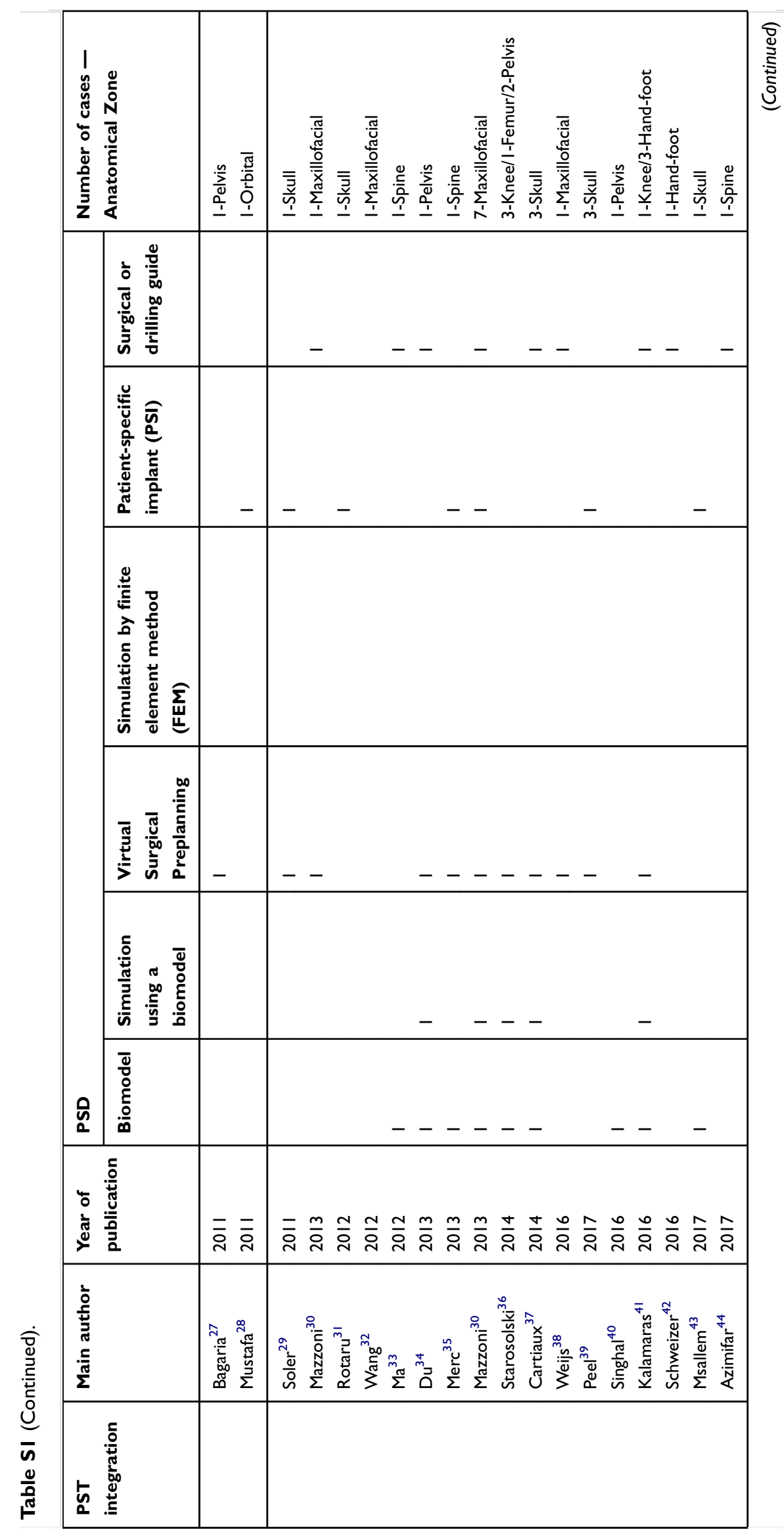




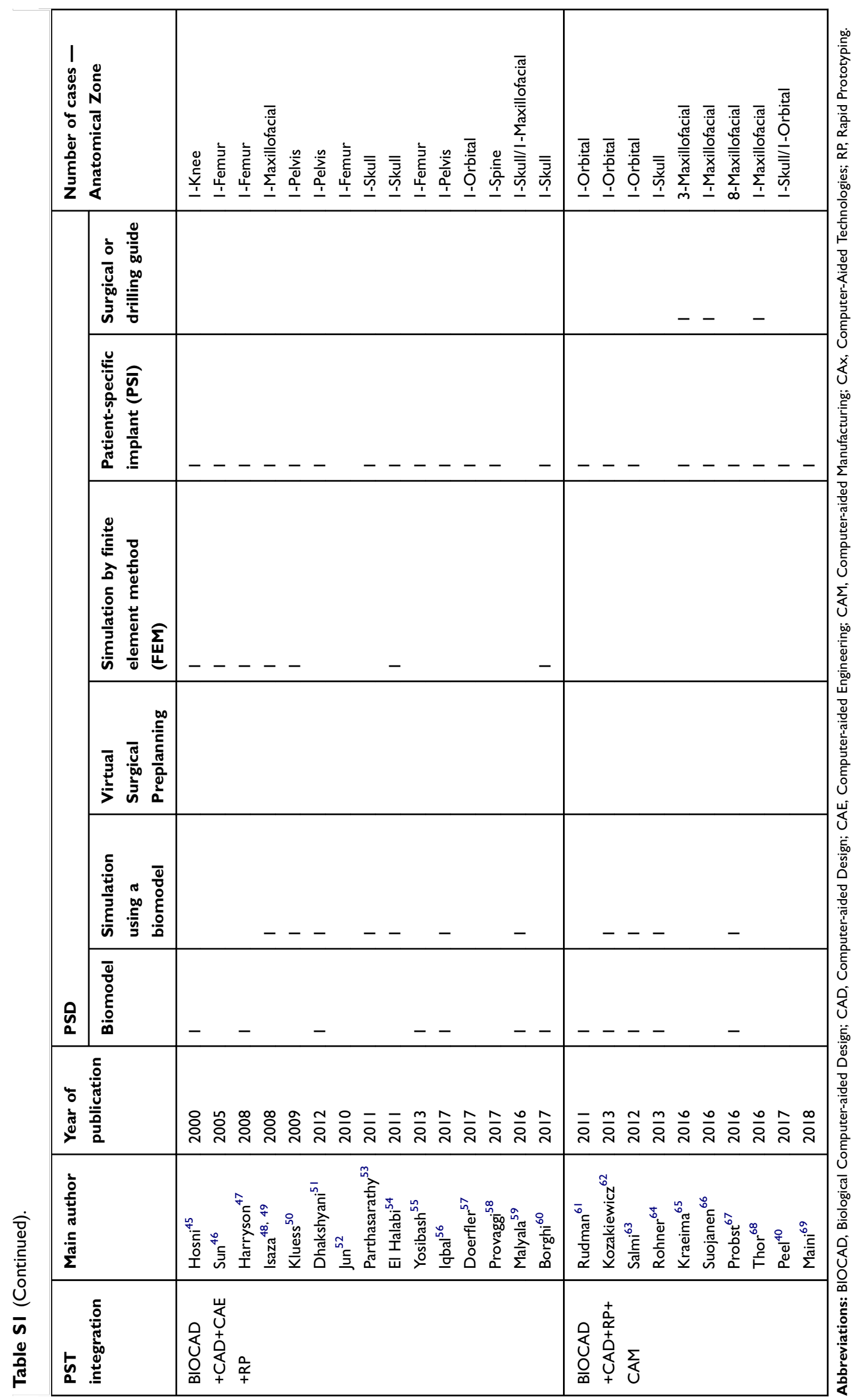




\section{References}

1. Senalp A-Z, Kayabasi O, Kurtaran H. Static, dynamic and fatigue behavior of newly designed stem shapes for hip prosthesis using finite element analysis. Mater Des. 2007;28(5):1577-1583. doi:10.1016/j.matdes.2006.02.015

2. Barone S, Paoli A, Razionale A-V, Savignano R. Computer-aided modelling to simulate the biomechanical behaviour of customised orthodontic removable appliances. Int $J$ Interact Des Manuf. 2016;10(4):387-400. doi:10.1007/s12008-014-0246-z.

3. Bruns J, Habermann C-R, Rüther W, Delling D. The use of CT derived solid modelling of the pelvis in planning cancer resections. Eur J Surg Oncol. 2010;36(6):594-598. doi:10.1016/j.ejso.2009. 11.005 .

4. Chul Y, Shik W, Park T, Woo J, Koh K-S, Suk T. The accuracy of patient specific implant prebented with 3D-printed rapid prototype model for orbital wall reconstruction. J Craniomaxillofac Surg. 2017;45(6):928-936. doi:10.1016/j.jcms.2017.03.010

5. Owen B-D, Christensen G-E, Reinhardt J-M, Ryken TC. Rapid prototype patient-specific drill template for cervical pedicle screw placement. Comput Aided Surg. 2007;12(5):303-308. doi:10.3109/ 10929080701662826

6. Hu Y, Li H, Qiao G, Liu H, Ji A, Ye F. Computer-assisted virtual surgical procedure for acetabular fractures based on real $\mathrm{CT}$ data Injury. 2011;42(10):1121-1124. doi:10.1016/j.injury.2011.01.014

7. Défossez H-J-P, Serhan H. Managing design excellence tools during the development of new orthopaedic implants. $J$ Biomech Eng. 2014;135(November 2013):114506-1/11. doi:10.1115/1.4025323

8. Werner A, Lechniak Z, Skalski K, Ke K. Design and manufacture of anatomical hip joint endoprostheses using CAD/CAM systems. $J$ Mater Process Technol. 2000;107:181-186. doi:10.1016/S09240136(00)00682-8

9. Bauer A-S, Storelli D-A-R, Sibbel S-E, Mccarroll H-R, Lattanza L-L. Preoperative computer simulation and patient-specific guides are safe and effective to correct forearm deformity in children. $J$ Pediatr Orthop. 2017;37(7):504-510. doi:10.1097/BPO.00000000000000673

10. Ojeda CJ, Carlín J, Saavedra P, Moscol G, Almeida J. Diseño, Análisis por $\mathrm{Ct}$ y construcción por $\mathrm{CAD} / \mathrm{CAM}$ de endoprótesis femoral personalizada: caso de una paciente con subluxacion congénia. $8^{\circ}$ Congreso Iberoamericano de Ingeniería Mecánica; 2007; Cusco. doi:10.1094/PDIS-91-4-0467B

11. Faegh S, Müftü S. Load transfer along the bone-dental implant interface. J Biomech. 2010;43(9):1761-1770. doi:10.1016/j.jbiomech. 2010.02.017

12. Ammar -H-H, Ngan P, Crout R-J, Mucino V-H, Mukdadi O-M. Three-dimensional modeling and finite element analysis in treatment planning for orthodontic tooth movement. Am J Orthod Dentofac Orthop. 2004;139(1):e59-e71. doi:10.1016/j.ajodo.2010.09.020

13. Perestrelo P, Bártolo P, Torres M-P, Noritomi P, Silva J. Human cranium biomechanical simulation. High Value Manufacturing: Advanced Research in Virtual and Rapid Prototyping. 2013:531-536.

14. Mircheski I, Gradišar M. 3D finite element analysis of porous Tibased alloy prostheses. Comput Methods Biomech Biomed Engin. 2016;19(14):1531-1540. doi:10.1080/10255842.2016.1167881

15. Griza S, Kwietniewski C, Tarnowski G-A, et al. Fatigue failure analysis of a specific total hip prosthesis stem design. Int J Fatigue. 2008;30:1325-1332. doi:10.1016/j.ijfatigue.2007.11.005

16. Thevenot J, Koivumäki J, Kuhn V, Eckstein F, Jämsä T A novel methodology for generating 3D finite element models of the hip from 2D radiographs. J Biomech. 2014;47(2):438-444. doi:10.1016/j. jbiomech.2013.11.004

17. Moiduddin K, Darwish S, Al-Ahmari A, ElWatidy S, Mohammad A, Ameen W. Structural and mechanical characterization of custom design cranial implant created using additive manufacturing. Electron $J$ Biotechnol. 2017;29:22-31. doi:10.1016/j.ejbt.2017.06.005.
18. Rashid -M-M, Husain K-N. Geometrical model creation methods for human humerus bone and modified cloverleaf plate. J Sci Ind Res. 2017;76(October):631-639.

19. Heissler E, Fischer F, Lehmann S-B-T, et al. Custom-made cast titanium implants produced with $\mathrm{CAD} / \mathrm{CAM}$ for the reconstruction of cranium defects. Int J Oral Maxillofac Surg. 1998;27(5):334-338.

20. Gibson I, Cheung L-K, Chow S-P, et al. The use of Rapid Prototyping to assist medical applications. Rapid Prototyping Journal. 2014;12 (1):53-58. doi:10.1108/13552540610637273.

21. Singare S, Dichen L, Bingheng L, Yanpu L, Zhenyu G, Yaxiong L. Design and fabrication of custom mandible titanium tray based on rapid prototyping. Med Eng Phys. 2004;26(8):671-676. doi:10.1016/ j.medengphy.2004.06.001.

22. Dai K-R, Yan M-N, Zhu Z-A, Sun Y-H Computer-aided custommade hemipelvic prosthesis used in extensive pelvic lesions. $J$ Arthroplasty. 2007;22(7):981-986. doi:10.1016/j.arth.2007.05.002

23. White D, Chelule K-L, Seedhom B-B. Accuracy of MRI vs CT imaging with particular reference to patient specific templates for total knee replacement surgery. Int J Med Robot Comput Assist Surg. 2008;4(August):224-231. doi:10.1002/rcs

24. Kunz M, Rudan JF, Xenoyannis GL, Ellis RE. Computer-assisted hip resurfacing using individualized drill templates. J Arthroplasty. 2010;25(4):600-606. doi:10.1016/j.arth.2009.03.023

25. Casallo C-A, Tantas G, Pineda R-A. Craneoplastía con implante de polieteretercetona diseñado por computadora. Acta Med Per. 2010;27 (3):193-195

26. Zhang Y-Z, Lu S, Yang Y, Xu Y-Q, Li Y-B, Pei G-X. Design and primary application of computer-assisted, patient-specific navigational templates in metal-on-metal hip resurfacing arthroplasty. $J$ Arthroplasty. 2011;26(7):1083-1087. doi:10.1016/j.arth.2010.08.004

27. Bagaria V, Deshpande S, Rasalkar -D-D, Kuthe A, Paunipagar B-K. Use of rapid prototyping and three-dimensional reconstruction modeling in the management of complex fractures. Eur J Radiol. 2011;80 (3):814-820. doi:10.1016/j.ejrad.2010.10.007

28. Mustafa SF, Evans PL, Bocca A, Patton DW, Sugar AW, Baxter PW. Customized titanium reconstruction of post-traumatic orbital wall defects: a review of 22 cases. Int J Oral Maxillofac Surg. 2011;40 (12):1357-1362. doi:10.1016/j.ijom.2011.04.020

29. Soler R, Moreno J-L, Cabrera C. Implante craneano individual de gran volumen en polimetilmetacrilato de metilo a partir de un prototipo rápido. Reporte de un caso. Odontoestomatologia. 2011;13 (17):26-36.

30. Mazzoni S, Marchetti C, Sgarzani R, Cipriani R, Scotti R, Ciocca L. Prosthetically guided maxillofacial surgery: evaluation of the accuracy of a surgical guide and custom-made bone plate in oncology patients after mandibular reconstruction. Plast Reconstr Surg. 2013;131(6):1376-1385. doi:10.1097/PRS.0b013e31828bd6b0

31. Rotaru H, Stan H, Florian IS, et al. Cranioplasty with custom-made implants: analyzing the cases of 10 patients. J Oral Maxillofac Surg. 2012;70(2):e169-e176. doi:10.1016/j.joms.2011.09.036

32. Wang G, Li J, Khadka A, Hsu Y, Li W, Hu J. CAD/CAM and rapid prototyped titanium for reconstruction of ramus defect and condylar fracture caused by mandibular reduction. Oral Surg Oral Med Oral Pathol Oral Radiol. 2012;113(3):356-361. doi:10.1016/j.tripleo. 2011.03.034

33. Ma T, Xu Y-Q, Cheng Y-B, et al. A novel computer-assisted drill guide template for thoracic pedicle screw placement: A cadaveric study. Arch Orthop Trauma Surg. 2012;132(1):65-72. doi:10.1007/ s00402-011-1383-5

34. Du H, Tian -X-X, Li T, et al. Use of patient-specific templates in hip resurfacing arthroplasty: experience from sixteen cases. Int Orthop. 2013;37(5):777-782. doi:10.1007/s00264-013-1842-4

35. Merc M, Drstvensek I, Vogrin M, Brajlih T, Recnik G. A multi-level rapid prototyping drill guide template reduces the perforation risk of pedicle screw placement in the lumbar and sacral spine. Arch Orthop Trauma Surg. 2013;133(7):893-899. doi:10.1007/s00402-013-1755-0 
36. Starosolski Z-A, Kan J-H, Rosenfeld S-D, Krishnamurthy R, Annapragada A. Application of 3-D printing (rapid prototyping) for creating physical models of pediatric orthopedic disorders. Pediatr Radiol. 2014;44(2):216-221. doi:10.1007/s00247-0132788-9

37. Cartiaux O, Paul L, Francq B, Banse X, Docquier P-L. Improved accuracy with $3 \mathrm{D}$ planning and patient-specific instruments during simulated pelvic bone tumor surgery. Ann Biomed Eng. 2014;42 (1):205-213. doi:10.1007/s10439-013-0890-7

38. Weijs W-L-J, Coppen C, Schreurs R, et al. Accuracy of virtually 3D planned resection templates in mandibular reconstruction. $J$ Craniomaxillofac Surg. 2016;44(11):1828-1832. doi:10.1016/j. jcms.2016.08.024

39. Peel S, Bhatia S, Eggbeer D, Morris D-S, Hayhurst C. Evolution of design considerations in complex craniofacial reconstruction using patient-specific implants. Proc IMechE Part H: J Engineering in Medicine. 2017;231:509-524. doi:10.1177/0954411916681346

40. Singhal A-J, Shetty V, Bhagavan K-R, et al. Improved surgery planning using 3-D printing: a case study. Indian J Surg. 2016;78 (April):100-104. doi:10.1007/s12262-015-1326-4

41. Kalamaras M, McEniery P, Thorn K, Bindra R. Rapid prototyping and 3D modeling of osteotomy jigs and drill guides in hand and wrist surgery. Tech Orthop. 2016;31(3):164-171. doi:10.1097/BTO.00000 00000000185

42. Schweizer A, Mauler F, Vlachopoulos L, Nagy L, Fürnstahl P. Computer-assisted 3-dimensional reconstructions of scaphoid fractures and nonunions with and without the use of patient-specific guides: early clinical outcomes and postoperative assessments of reconstruction accuracy. J Hand Surg Am. 2016;41(1):59-69. doi:10.1016/j.jhsa.2015.10.009

43. Msallem B, Jaquiéry C, Thieringer F, Jaquiéry C, Thieringer F. Craniofacial reconstruction by a cost-efficient template-based process using 3D printing. Plast Reconstr Surg Glob Open. 2017;5(11):1-5. doi:10.1097/GOX.0000000000001582

44. Azimifar F, Hassani K, Saveh A-H, Tabatabai-Ghomshe F A low invasiveness patient's specific template for spine surgery. Proc IMechE Part H J Eng Med. 2017;231(2):143-148. doi:10.1177/ 0954411916682770.

45. Hosni Y-A Contribution of CAD-CAM and reverse engineering technology to the biomedical field. In: Current Advances in Mechanical Design and Production VII. Cairo: Pergamon; 2000:491-499.

46. Sun W, Starly B, Nam J, Darling A Bio-CAD modeling and its applications in computer-aided tissue engineering. Comput Des. 2005;37(11):1097-1114. doi:10.1016/j.cad.2005.02.002

47. Harrysson O-L-A, Cansizoglu O, Marcellin-Little D-J, Cormier D-R, West H-A Direct metal fabrication of titanium implants with tailored materials and mechanical properties using electron beam melting technology. Mater Sci Eng C. 2008;28(3):366-373. doi:10.1016/j. msec.2007.04.022

48. Isaza J-F Prototipaje rápido de estructuras craneofaciales. Ing $Y$ Cienc. 2008;4(8):27-43.

49. Isaza JF, Correa S Metodología para la reconstrucción 3D de estructuras craneofaciales y su utilización en el método de elementos finitos. Ing Y Cienc. 2008;4(7):129-149.

50. Kluess D, Souffrant R, Mittelmeier W, Wree A, Schmitz K-P, Bader R. A convenient approach for finite-element-analyses of orthopaedic implants in bone contact: modeling and experimental validation. Comput Methods Programs Biomed. 2009;95(1):23-30. doi:10.10 16/j.cmpb.2009.01.004

51. Dhakshyani R, Nukman Y, Azuan A-O-N FDM models and FEA in dysplastic hip. Rapid Prototyp J. 2012;18(3):215-221. doi:10.1108/ 13552541211218144

52. Jun Y, Choi K Design of patient-specific hip implants based on the 3D geometry of the human femur. Adv Eng Softw. 2010;41(4):537547. doi:10.1016/j.advengsoft.2009.10.016
53. Parthasarathy J, Starly B, Raman S A design for the additive manufacture of functionally graded porous structures with tailored mechanical properties for biomedical applications. J Manuf Process. 2011;13(2):160-170. doi:10.1016/j.jmapro.2011.01.004

54. El Halabi F, Rodriguez JF, Rebolledo L, Hurtós E, Doblaré M. Mechanical characterization and numerical simulation of polyetherether-ketone (PEEK) cranial implants. J Mech Behav Biomed Mater. 2011;4(8):1819-1832. doi:10.1016/j.jmbbm.2011.05.039

55. Yosibash Z, Katz A, Milgrom C. Toward verified and validated FE simulations of a femur with a cemented hip prosthesis. Med Eng Phys. 2013;35(7):978-987. Doi:10.1016/j.medengphy.2012.09.007

56. Iqbal T, Shi L, Wang L, et al. Development of finite element model for customized prostheses design for patient with pelvic bone tumor. Proc IMechE Part H: J Engineering in Medicine. 2017;231:525-533. doi:10.1177/0954411917692009.

57. Doerfler H-M, Huempfner-hierl H, Kruber D, Schulze P, Hierl T. Template-based orbital wall fracture treatment using statistical shape analysis. J Oral Maxillofac Surg. 2017;75(7):1475.e1-1475.e8. doi:10.1016/j.joms.2017.03.048

58. Provaggi E, Leong -J-J-H, Kalaskar D-M. Applications of 3D printing in the management of severe spinal conditions. 2 Proc IMechE Part H: J Engineering in Medicine. 2017;231:471-486. doi:10.1177/ 0954411916667761

59. Malyala S-K, Alwala A-M A 3D printed osseointegrated combined jaw and dental implant prosthesis - a case study. Rapid Prototyp $J$. 2016;23(6):1164-1169.

60. Borghi A, Rodgers Ã, Schievano Ã, et al. Proof of concept study for the design, manufacturing, and testing of a patient-specific shape memory device for treatment of unicoronal craniosynostosis. $J$ Craniofac Surg. 2017:1-4. doi:10.1097/SCS.0000000000004025

61. Rudman K, Hoekzema C, Rhee J. Computer-assisted innovations in craniofacial surgery. Facial Plast Surg. 2011;27(4):358-365. doi:10.1055/s-0031-1283054

62. Kozakiewicz M, Elgalal M, Walkowiak B, Stefanczyk L Technical concept of patient-specific, ultrahigh molecular weight polyethylene orbital wall implant. J Craniomaxillofac Surg. 2013;41(4):282-290. doi:10.1016/j.jcms.2012.10.007.

63. Salmi M, Tuomi J, Paloheimo K-S, et al. Patient-specific reconstruction with 3D modeling and DMLS additive manufacturing. Rapid Prototyp J. 2012;18(3):209-214. doi:10.1108/13552541211218126.

64. Rohner D, Guijarro-Martínez R, Bucher P, Hammer B Importance of patient-specific intraoperative guides in complex maxillofacial reconstruction. J Craniomaxillofac Surg. 2013;41(5):382-390. doi:10.10 16/j.jcms.2012.10.021

65. Kraeima J, Jansma J, Schepers R-H Splintless surgery: does patientspecific CAD-CAM osteosynthesis improve accuracy of Le Fort I osteotomy? Br J Oral Maxillofac Surg. 2016;54(10):1085-1089. doi:10.1016/j.bjoms.2016.07.007.

66. Suojanen J, Leikola J, Stoor P The use of patient-specific implants in orthognathic surgery: A series of 32 maxillary osteotomy patients. $J$ Craniomaxillofac Surg. 2016;44(12):1913-1916. doi:10.1016/j. jcms.2016.09.008.

67. Probst F-A, Metzger M, Ehrenfeld M, Cornelius C-P Computerassisted designed and manufactured procedures facilitate the lingual application of mandible reconstruction plates. J Oral Maxillofac Surg. 2016;74(9):1879-1895. doi:10.1016/j.joms.2016.03.015.

68. Thor A, Palmquist A, Hirsch J-M, Rännar L-E, Dérand P, Omar O. Clinical, morphological, and molecular evaluations of bone regeneration with an additive manufactured osteosynthesis plate. J Craniofac Surg. 2016;27(7):1899-1904. doi:10.1097/SCS.0000000000002939

69. Maini L, Sharma A, Jha S, Tiwari A Three-dimensional printing and patient-specific pre-contoured plate : future of acetabulum fracture fixation? Eur J Trauma Emerg Surg. 2018;44:215-224. doi:10.1007/ s00068-016-0738-6. 


\section{Publish your work in this journal}

Medical Devices: Evidence and Research is an international, peerreviewed, open access journal that focuses on the evidence, technology, research, and expert opinion supporting the use and application of medical devices in the diagnosis, monitoring, treatment and management of clinical conditions and physiological processes. The identification of novel devices and optimal use of existing devices which will lead to improved clinical outcomes and more effective patient management and safety is a key feature of the journal. The manuscript management system is completely online and includes a very quick and fair peer-review system. Visit http:// www.dovepress.com/testimonials.php to read real quotes from published authors.

Submit your manuscript here: https://www.dovepress.com/medical-devices-evidence-and-research-journal 